\title{
Scholar, Clinical and Emotional Maladjustment in 8-12 School-Age Children: Adaptation of the Self-Report Version of the Behavior Assessment System for Children (BASC-S2) to the Basque-Speaking Population*
}

\author{
Joana Jaureguizar, Elena Bernaras, Izaskun Ibabe, and Marta Sarasa \\ Universidad del País Vasco / Euskal Herriko Unibertsitatea
}

\begin{abstract}
Emotional disorders influence pupils' school adjustment, but there are some serious deficiencies as regards the identification of the children in question. Hence the need for reliable and valid diagnostic tools. The objectives of this study are twofold: to study the rates of school maladjustment, clinical maladjustment and emotional symptoms according to sex and age; and to adapt to the Basque language (euskara) and subsequently validate the Behavior Assessment System for Children (BASC), in its selfreport version for pupils aged 8 to 12 years (S2). Participants were 795 pupils from seven schools in the Basque Country Autonomous Region. Fifteen per cent of the pupils presented school maladjustment, the rate in boys being higher than in girls. Thirteen per cent also presented emotional symptoms, which were especially detected in 12-year-old girls. As regards the Basque version of the BASC-S2, its psychometric properties were found to be adequate.
\end{abstract}

Keywords: School adjustment, emotional symptoms, adaptation, validation, Basque (euskara).

\section{Resumen}

Los trastornos emocionales influyen en el ajuste escolar del alumnado, pero la identificación de estos niños presenta muchos déficits. De ahí la necesidad de contar con herramientas diagnósticas fiables y válidas. Este estudio tiene un doble objetivo: estudiar la tasa de desajuste escolar, desajuste clínico y síntomas emocionales en función del sexo y la edad; y la adaptación al euskara y la consiguiente validación del Behavior Assessment System for Children (BASC) en su versión de autoinforme para alumnado de 8 a 12 años (S2). Han participado 795 estudiantes de siete centros escolares de la Comunidad Autónoma Vasca. El 15\% de los escolares presenta síntomas de desajuste escolar, siendo el nivel de los varones mayor que el de las niñas. El 13\% de los escolares también presenta síntomas emocionales, especialmente presentes en las niñas de 12 años. La versión vasca del BASC-S2, por su parte, presenta características psicométricas adecuadas.

Palabras clave: Ajuste escolar, síntomas emocionales, adaptación, validación, euskara.

Correspondence: Joana Jaureguizar. Dpto. de Psicología Evolutiva y de la Educación. Universidad del País Vasco-Euskal Herriko Unibertsitatea. EU Magisterio de Leioa. Barrio Sarriena s/n. Leioa (Bizkaia), Spain. E-mail: joana.jauregizar@ehu.es.

* This work was funded by the Basque Government (AE-2010-1-22) and the University of the Basque Country/Euskal Herriko Unibertsitatea (UPV/EHU) UFI 11/04. 


\section{Introduction}

The early assessment of emotional and behavioral problems in schoolchildren is one of the priority goals of child and adolescent mental health research, since it will permit the development of adequate intervention strategies and the prevention of disorders in adolescence and into adulthood. However, children with emotional disorders are among the populations whose identification and treatment is particularly difficult (Reddy \& Richardson, 2006). There are some studies with Spanish clinical and school samples that have analyzed the most prevalent diagnostic categories in the child and adolescent population (Aláez, Martínez-Arias, \& Rodríguez-Sutil, 2000; Bragado, Carrasco, Sánchez, \& Bersabe, 1996; López-Soler, Castro, Alcántara, Fernández, \& López Pina, 2009; Romero et al., 2010). Such studies are normally carried out with samples from different age ranges and based on very different measurement instruments, which means that some degree of caution is necessary on generalizing the results. In the studies with clinical samples the most prevalent diagnostic categories are anxiety disorders (range of 13.3$41.16 \%$ ), followed by behavior disorders (range of 18.1-34.25\%), and finally, depressive disorders (range of 9.94-14.6) (Aláez et al., 2000; Bragado et al., 1996; López-Soler et al., 2009). However, taking into account recent studies with sam- ples of schoolchildren aged 6 to 12 (Romero et al., 2010), it can be observed that the figures for anxiety disorders rise to $47 \%$ and those for depression are between $9.07 \%$ and $11.5 \%$, depending on the instrument used. International studies, such as the meta-analysis by Twenge, Gentile, DeWall, Ma, Lacefield and Schurtz (2010), which involved a comparison with cohorts over the period 1938-2007, show an increase in psychopathology (such as anxiety and depression disorders) among schoolchildren.

Traditionally, studies on the prevalence of emotional and behavior disorders tend to pay particular attention to differences by sex and age (Aláez et al., 2000), though research results are contradictory. Some international studies indicate a greater tendency for emotional symptomatology in girls, particularly anxiety symptoms (Axelson \& Birmaher, 2001; Crijnen, Achenbach, \& Verhulst, 1999) or depressive symptoms as adolescence approaches (Angold, Erkanli, Silberg, Eaves, \& Costello, 2002), while other research reports similar rates of emotional problems (especially anxiety and depression) in boys and girls under 14 (Essau, Conradt, \& Petermann, 2000), and even higher rates of depressive disorders in boys (Angold, Costello, \& Worthman, 1998). Differences by sex have also been found in relation to the predictors of child depression. Thus, in boys, anxiety in itself is a good predictor, while in girls the predictors 
of depression are anxiety, worry and hypersensitivity (Kovacs, 2010). Age is another variable that must be taken into account, since, for example, the onset of major depressive disorders tends to be around the ages of 11-12, though the first signs of less severe depressive disorders are mainly observed around age 7-8 (Del Barrio, 2000).

According to previous studies, problems of school adjustment are associated with both emotional disorders and behavior disorders (Denham, 2006; Fleming \& Offord, 1990; Herman, Lambert, Ialongo, \& Ostrander, 2008; Olson \& Hoza, 1993). Children with depressive symptoms have difficulty concentrating on their studies, and find it hard to get good grades (Cole, 1991; Patterson \& Stoolmiller, 1991; Roeser, van der Wolf, \& Strobel, 2001) or do their homework properly (Cancio, West, \& Young, 2004), leading to an increase in their feelings of inadequacy, both social and academic (negative academic selfconcept). These children perceive that they can do little to improve their academic performance (external locus of control), and this actually increases their depressive symptomatology. Nevertheless, it is also true that low school performance constitutes a risk factor for depression (Herman et al., 2008), since poor academic performance feeds the negative self-concept that the child has been building up over his or her school life, knocking his or her self-confidence as a student.
Therefore, adequate detection of these types of disorder - through wide-ranging assessment systems covering various diagnostic dimensions - and the training of different professionals that come into contact with the child (school psychologists and teachers) become essential aspects for the promotion of children's appropriate personal and school adjustment.

The most widely used nosological classifications correspond to one of two broad models: the medical-categorical model and the dimensional psychometric model. The medical-categorical model, which would include the DSM-IV-TR (American Psychiatric Association, APA, 2002) and the ICD-10 (World Health Organization, WHO, 1992), employs qualitative and subjective criteria to establish the presence of disorders, understands mental disorders as discrete entities, and basically uses the interview to arrive at a diagnosis (Del Barrio, 1995; Lacalle, 2009). However, in the child and adolescent context, the dimensional psychometric model is taking on more relevance, a model that uses quantitative procedures to determine empirically which characteristics tend to co-occur in the different forms of syndromes, to reach an assessment of the degree of intensity of the problem (Lacalle, 2009). One of the instruments that falls within the framework of this dimensional model and is widely used in the clinical and school field is Reynolds and Kamphaus's (1992) 
Behaviour Assessment System for Children (BASC), since it provides a more integrated, less partial assessment (Carney \& Merrell, 2002). Holmbeck et al. (2008) identify as strong points of the BASC that it provides the "structured history of the individual's development," a "system of observation of the pupil," several subscales not included in the CBCL (such as self-esteem, self-reliance, locus of control or sense of inadequacy) and a whole series of validity indices ( $F$ Index, a measure of the tendency to respond in an over-negative way about one's own perceptions and emotions; V Index, a basic measure of the general validity of the questionnaire scores; ICR Index, of the internal consistency of the responses; and PTR Index, of pattern of responses). The global scales of this instrument have been used in recent research on psychopathology and maladjustment (Escobar, Fernández-Baena, Miranda, Trianes, \& Cowie, 2011; Escobar, Trianes, Fernández-Baena, \& Miranda, 2010; Keane \& Calkins, 2004).

One of the most relevant measures in the BASC is the scale for the diagnosis of depressive symptomatology (Del Barrio, 2010). Bearing in mind the early onset of depressive symptomatology (Ferguson \& Woodward, 2002; Kovacs, Feinberg, Crouse-Novak, Paulauskas, \& Finkelstein, 1984; Reinherz, Giaconia, Carmola, Wasserman, \& Paradis, 2000), early detection takes on special relevance. Therefore, it is extremely useful to have access to screening instruments which provide information on not only depressive symptomatology but also many other emotional and behavioural dimensions of the child and adolescent.

Taking into account all of the above, the main aim of the present work was to study the rates of school maladjustment, clinical maladjustment and emotional symptoms in a sample of schoolchildren from the Basque Country and to identify possible differences according to sex and age. Given the linguistic reality of the Basque Country - according to data from the Basque Institute of Statistics (EUSTAT, 2011), 91.19\% of primary school children follow Model D (exclusively in Basque) or B (bilingual Basque-Spanish) - , a second objective emerged from the study: the adaptation to Basque and subsequent validation of the BASC in its self-report version for 8 to 12 -yearolds (S2). This involved verifying whether the factor structure of this Basque version corresponds to that of the original model and to that of the model in the Spanish adaptation, which had three factors (personal adjustment, clinical maladjustment and school maladjustment) (see Appendices 1 and 2), by means of two analysis strategies: exploratory analysis and confirmatory analysis. Likewise, we set out to assess the internal consistency (Cronbach's alpha) of the instrument and to provide data on its concurrent validity. 


\section{Method}

\section{Participants}

Participants in this study were 795 boys and girls (47\% boys) aged 8 to 12 years $(M=9.65$; $S D=1.2)$ from seven schools in the Basque Country (four public and three grant-assisted schools; three schools from provincial capitals and another four from large, medium and small municipalities). Mean age of the boys was 9.70 years, while girls' mean age was 9.58 years. By grades, 25\% $(n=196)$ were in grade 3 of primary education, $25 \%(n=199)$ were in 4th grade, $27 \%(n=217)$ were in 5 th grade and $23 \%$ $(n=182)$ were in 6 th grade.

\section{Measurement instruments}

\section{Behavior Assessment} System for Children (BASC,

Reynolds \& Kamphaus, 1992)

The BASC is a multidimensional assessment system designed for rating dimensions both positive (adaptive scales) and negative (clinical scales) of the behavior and personality of children and adolescents. Moreover, it provides information from multiple sources: selfreport $(\mathrm{S})$, parent $(\mathrm{P})$ and homeroom teacher $(\mathrm{T})$. The questionnaires differ according to respondent's age: level 1 (3-6 years), level 2 (612 years) and level 3 (12-18 years). In the case of the Self-Report (S), there are two levels of application: children aged 6-12 (S2) and adolescents aged 12-18 (S3). The BASC components can be used in isolation or as a full set. In this study we administered only the Self-Report (S2), which includes 146 statements and 12 scales, grouped in 8 clinical scales (see Box 1) and four adaptive scales (see Box 2). It was decided to use the self-report because, in contrast to the case of other questionnaires that can be completed by homeroom teachers or parents, the self-report records what is happening in the children's internal world, providing rich data on their thoughts, feelings, attitudes and reactions in response to their environment (González, Fernández, Pérez, \& Santamaría, 2004). Reliability of the global dimensions of the BASC S-2 in its Spanish adaptation ranged from .77 to .91 , with an average value of .86 .

The 12 scales defined are grouped in four global dimensions: personal adjustment (made up of the interpersonal relations, relations with parents, self-reliance and selfesteem scales), clinical maladjustment (made up of the anxiety, atypicality and locus of control scales), school maladjustment (made up of the negative attitude to school and negative attitude to teachers scales) and index of emotional symptoms. The last of these represents a global indicator of emotional alterations, specifically of internalizing problems. It is made up of the anxiety, interpersonal relations, self-esteem, 


\section{Chart 1}

Clinical Scales of the BASC-S2

\begin{tabular}{cl}
\hline \multicolumn{1}{c}{ Scale } & \multicolumn{1}{c}{ Definition } \\
\hline $\begin{array}{c}\text { Negative attitude } \\
\text { to school }\end{array}$ & $\begin{array}{l}\text { Feelings of alienation, hostility and dissatisfaction in relation to } \\
\text { school }\end{array}$ \\
\hline $\begin{array}{c}\text { Negative attitude } \\
\text { to teachers }\end{array}$ & $\begin{array}{l}\text { Feelings of antipathy toward teachers; beliefs that teachers are unfair, } \\
\text { that they pay insufficient attention to the pupils, or that they are too } \\
\text { demanding }\end{array}$ \\
\hline Atypicality & $\begin{array}{l}\text { Tendency for sharp mood swings, strange ideas, unusual experiences } \\
\text { or obsessive-compulsive thoughts and behaviors considered "odd" }\end{array}$ \\
\hline Locus of control & $\begin{array}{l}\text { Belief that rewards and punishments are controlled by external events } \\
\text { or by other people }\end{array}$ \\
\hline Social stress & $\begin{array}{l}\text { Level of stress experienced by children and adolescents in their inter- } \\
\text { action with others }\end{array}$ \\
\hline Anxiety & $\begin{array}{l}\text { Feelings of nervousness, worry and fear; tendency to feel over- } \\
\text { whelmed by problems }\end{array}$ \\
\hline Depression & $\begin{array}{l}\text { Usual symptoms of depression, including feelings of loneliness and } \\
\text { sadness and inability to enjoy life }\end{array}$ \\
\hline $\begin{array}{c}\text { Sense of } \\
\text { inadequacy }\end{array}$ & $\begin{array}{l}\text { Perceptions of failure at school, of difficulty in achieving one's goals, } \\
\text { and of general lack of ability }\end{array}$ \\
\hline
\end{tabular}

Chart 2

Adaptive Scales of the BASC-S2

\begin{tabular}{cl}
\hline Scale & Definition \\
\hline $\begin{array}{c}\text { Interpersonal } \\
\text { relations }\end{array}$ & Perception of having good social relations and friendships with peers \\
\hline $\begin{array}{c}\text { Relations with } \\
\text { parents }\end{array}$ & Positive consideration of parents and feeling that they respect you \\
\hline Self-esteem & Feelings of self-esteem, self-respect and self-acceptance \\
\hline Self-reliance & $\begin{array}{c}\text { Confidence in one's own ability to solve problems, belief in one's in- } \\
\text { dependence and in one's capacity to make one's own decisions }\end{array}$ \\
\hline
\end{tabular}


social stress, depression and sense of inadequacy scales.

\section{Children's Depression Scale} (CDS; Lang \& Tisher, 1983)

In its Basque version (Balluerka, Gorostiaga, \& Haranburu, under review). This instrument was designed to be administered to children and adolescents aged 8 to 16 , with an application time of $30-40$ minutes. It is made up of 66 elements, the majority of which are formulated in terms of depression, affirming a situation indicative of this disorder; the rest refer to situations that do not present depressive content. Two broad dimensions are obtained - Total depressive and Total positive - and 8 subscales -Affective response, Social problems, Self-esteem, Preoccupation with death, Guilt, Miscellaneous depressive items, Pleasure and enjoyment, and Miscellaneous positive items (ability to experience pleasure)-. The first 6 subscales (48 items) are grouped in a Total Depressive Score and the last 2 subscales (18 items) in a Total Positive Score. The Basque adaptation of the instrument showed excellent internal consistency for Total Depressive $(\alpha=.95)$ and an acceptable level for Total Positive $(\alpha=.75)$. These data coincide almost totally with the internal consistency results for the present study: $\alpha=.94$ for Total Depressive and $\alpha=.74$ for Total Positive.

\section{Procedure}

\section{Translation of items}

A back-translation process was carried out on the BASC-S2 items following the recommendations of Hambleton and Patsula (1999) for the adaptation of a measurement instrument from one culture to another. Each element of the Spanish version was translated into Basque by two independent professional translators. The two translations were compared, discussed, and reduced to a single agreed version. On the basis of this version, two translators with profiles similar to those used in the previous phase translated the Basque version into Spanish. After comparing the two versions, a single Spanish version of the BASC was obtained. Finally, the members of the research team compared each item of the original Spanish version with the version adapted inversely, checking for possible lack of equivalence of meaning. As a result of this analysis, some changes were made to the Basque version of the BASC.

\section{Presentation of the project in the schools and application of the instruments}

The study was presented to the head teachers at the schools, who in turn presented it for approval at a staff meeting. With the schools who agreed to participate it was arranged for the families to be sent 
an informed consent protocol. The participating students handed in the informed consent to their homeroom teachers, prior to the administration of the instruments. Participants were informed that the results would be totally confidential and that anonymity would be maintained. The two questionnaires (BASC-S2 and CDS) were administered collectively in each class, and in a single session during normal school time. The whole process took roughly one hour. The instructions for the two questionnaires were read aloud. Application took place over a twelve-month period (2010-2011) and was by psychologists and research students especially trained for this purpose. The statistics package PASW18 and version 6.1 of the EQS program were used for the data analysis. All those cases that failed to meet the validity criteria in accordance with the $\mathrm{F}$ and $\mathrm{V}$ validity indices of the BASC were removed.

\section{Data analysis}

First of all, percentages for rates of maladjustment and emotional symptoms were calculated, the following step being to carry out three $2 \times 3$ ANOVAs with participant's sex (boy vs. girl) $\times$ age $(8-9$ years; 10-11 years; and 12 years); dependent variables were school maladjustment, clinical maladjustment and emotional symptoms. Furthermore, we obtained a regression model for the prediction of school maladjust- ment, based on both the clinical scales and the adaptive scales of the BASC.

Secondly, the factor structure of the scale was analyzed by means of principal components analysis with Oblimin rotation. Subsequently, we calculated the asymmetry and kurtosis indexes of the 12 scales. It is assumed that values of around 1 indicate slight divergence from the normal distribution, that values of between 1 and 2.3 are moderately abnormal, and that values of over 2.3 indicate marked abnormality (Lei \& Lomax, 2005). In the confirmatory factor analysis, for the examination of the models' goodness of fit, the following indices were used: the Chi-squared statistic divided by the degrees of freedom $\left(\chi^{2} / \mathrm{df}\right)$, the Comparative Fit Index (CFI), Bollen's Incremental Fit Index (IFI), the Bentler-Bonett Non-normative Fit Index (NNFI) and the Root Mean Square Error of Approximation (RMSEA). Values of $\chi^{2} / \mathrm{df}$ below 5 represent a good fit of the model (Bollen, 1989); in general, values of 0.8 or less on the RMSEA index are deemed acceptable, though some authors prefer to set the cut-off point at $.06(\mathrm{Hu} \&$ Bentler, 1999); and finally, values of over .90 on the CFI, IFI and NNFI indices are considered acceptable (Bentler, 2006).

In third place, Cronbach's alpha coefficients were generated for each factor to assess internal consistency (Cronbach, 1951), and Nunnally's (1978) alpha $\geq .70$ criterion 
was adopted for considering acceptable reliability in the Psychology field. On the basis that, by comparison with the School maladjustment or Clinical maladjustment dimensions, the items corresponding to the Personal adjustment dimension assess the construct in question inversely, these items were previously recoded. For example, to calculate the alpha coefficient of Personal adjustment it was necessary to recode the items referring to Depression because it is a negative scale, whilst the rest are positive.

\section{Results}

\section{School maladjustment, clinical maladjustment and emotional symptoms}

According to the scores obtained on the BASC S-2, $4.7 \%$ of the participants present school maladjustment, $4.2 \%$ clinical maladjustment and $4.4 \%$ clinically significant emotional symptoms. Moreover, $10.8 \%$ of the children are at risk of school maladjustment, $15.2 \%$ of clinical maladjustment, and $8.7 \%$ of presenting emotional symptoms. With the aim of checking whether the level of school maladjustment, clinical maladjustment and emotional symptoms varied according to participants' sex and age, we carried out three 2 (sex) $\times 3$ (age) ANOVAs with independent measures. In the
ANOVA for school maladjustment, only sex emerged as significant $[F(1,778)=8.98, p=.003]$, the level of school maladjustment being higher in boys $(M=54.4)$ than in girls $(M=50.3)$. In the ANOVA for clinical maladjustment the interaction is almost significant $[F(2$, $778)=2.80, p=.06)]$. The results of the third analysis revealed a significant main effect of sex $[F(1$, $779)=8.47, p=.004]$ and a significant interaction between sex and age $[F(2,779)=4.33, p=.01)]($ see figure 1). The interaction was analyzed by means of Tukey post-hoc tests, and it was verified that in the 12-year-olds' group the girls presented significantly more emotional symptoms than the boys $(p=.03)$, while in the other two groups there were no differences.

School maladjustment correlates significantly with emotional symptoms $(r=.32)$, clinical maladjustment $(r=.26)$, depression (CDS) $(r=.24)$ and sadness $(r=.26)$. A regression analysis was carried out including all the BASC scales, with the aim of analyzing which of them were predictor variables of school maladjustment. Two variables corresponding to the clinical scales (sense of inadequacy and locus of control) and another two variables of the adaptive scales (relations with parents and self-reliance) emerged as valid predictor factors of school maladjustment, the model explaining 21\% of the variance (see table 1). 


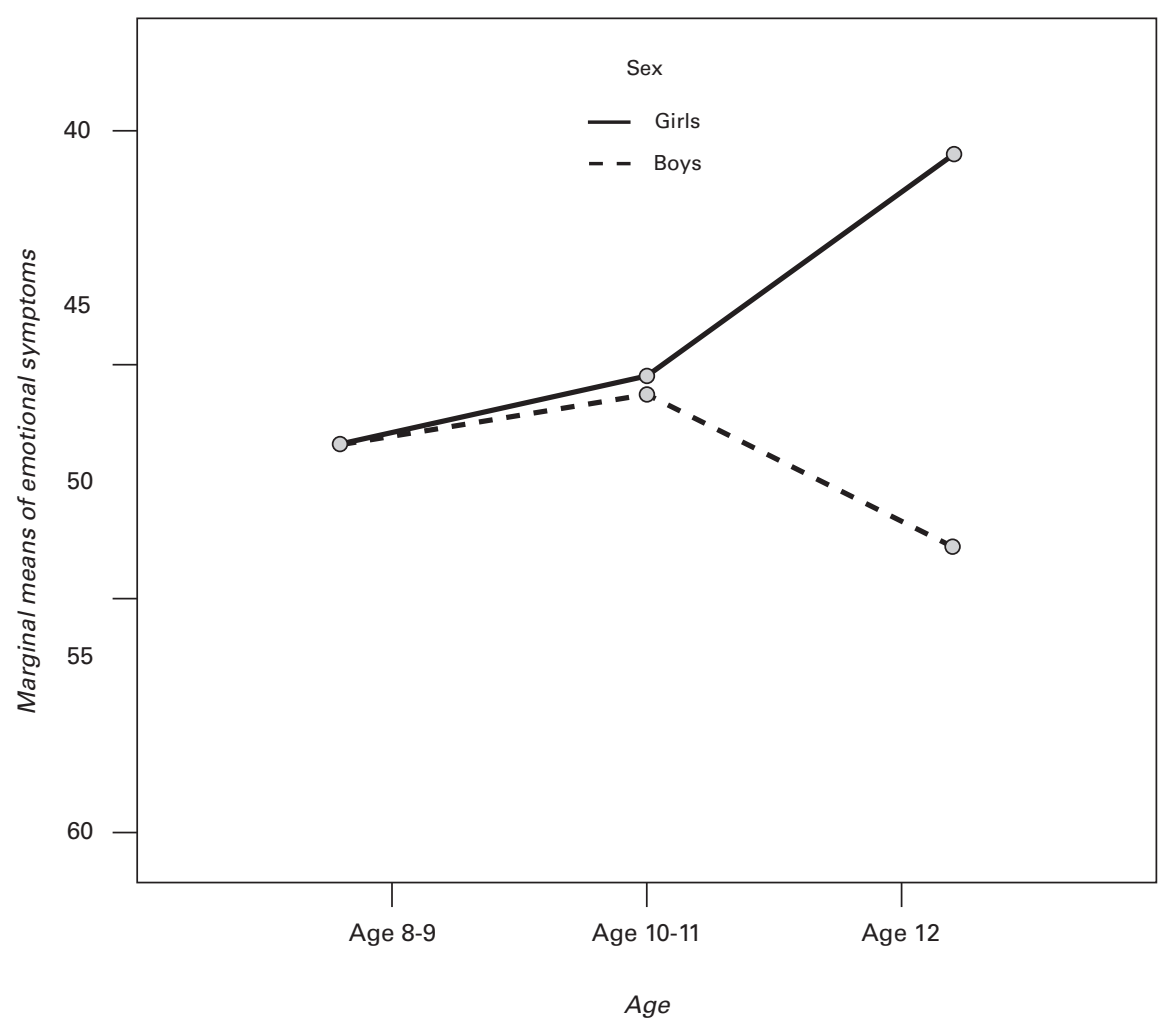

Figure 1. Level of emotional symptoms according to sex and age.

Table 1

Predictors of School Maladjustment

\begin{tabular}{lrrrrc}
\hline & \multicolumn{5}{c}{ School maladjustment } \\
\cline { 2 - 6 } & \multicolumn{1}{c}{$B$} & Type B error & \multicolumn{1}{c}{$\beta$} & \multicolumn{1}{c}{$T$} & \multicolumn{1}{c}{$p$} \\
\hline Constant & 45.81 & 2.90 & & 15.79 & .001 \\
Sense of inadequacy & .18 & .04 & .18 & 4.78 & .001 \\
Locus of control & .19 & .04 & .20 & 5.23 & .001 \\
Relations with parents & -.15 & .03 & -.17 & -5.00 & .001 \\
Self-reliance & -.11 & .03 & -.12 & -3.60 & .001 \\
\hline
\end{tabular}

Note: $R^{2}=.21, p<.001$. 


\section{Validation of the BASC-S2}

\section{Factor structure}

The Kaiser-Meyer-Olkin (KMO) value was .89 , which can be considered as adequate (Field, 2005), indicating that the sample size is acceptable for the quantity of variables to be analyzed. The Bartlett sphericity test is statistically significant $\chi^{2}$ $(66)=4621.74, p<.001$, signifying that the factor analysis is appropriate.

With the aim of examining the dimensionality of the scale, we carried out a principal components

Table 2

Configuration Matrix After the Principal Components Analysis and Oblimin Rotation

\begin{tabular}{|c|c|c|c|}
\hline & \multicolumn{3}{|c|}{ Factor } \\
\hline & 1 & 2 & 3 \\
\hline $\begin{array}{l}\text { Negative attitude to } \\
\text { school }\end{array}$ & & & .80 \\
\hline $\begin{array}{l}\text { Negative attitude to } \\
\text { teachers }\end{array}$ & & & .62 \\
\hline Atypicality & .82 & & \\
\hline Locus of control & .71 & & \\
\hline Social stress & .71 & & \\
\hline Anxiety & .84 & & \\
\hline Depression & .64 & & \\
\hline Sense of inadequacy & .66 & & \\
\hline Interpersonal relations & & .62 & \\
\hline Relations with parents & & .71 & \\
\hline Self-esteem & & .58 & \\
\hline Self-reliance & & .63 & \\
\hline
\end{tabular}

Note: Correlations of under I.40l were removed to facilitate interpretation. analysis with Oblimin rotation. In accordance with the Kaiser-Guttman standard criterion (initial eigenvalues higher than 1), 3 factors were identified that explained $60.5 \%$ of the total variance. The first factor (eigenvalue $=4.7$ ) explained $39 \%$ of the total variance and corresponded to the Clinical maladjustment dimension, the second factor (eigenvalue $=1.50$ ) represented $12.5 \%$, reflecting the Personal adjustment dimension, and the third factor (eigenvalue $=1.08$ ) represented 9\% and referred to School maladjustment (see table 2). Factor loadings of .40 and over were considered interpretable.

\section{Confirmatory factor analysis}

The confirmatory factor analysis (CFA) that constituted the starting point was the initial theoretical model (Reynolds \& Kamphaus, 1992). Of the total participants, 99.9\% $(n=787)$ had the complete data in this analysis, and the maximum likelihood method was used for dealing with lost values (e.g., Arbuckle, 1996; Jamshidian \& Bentler, 1998). A confirmatory factor analysis with 12 observed variables and 3 latent factors was carried out, each scale contributing to a single dimension. The latent variables included in the model were: Personal adjustment (indicators: Interpersonal relations, Relations with parents, Self-esteem and Self-reliance), School maladjustment (indicators: Negative attitude to school 
and Negative attitude to teachers) and Clinical maladjustment (Sense of inadequacy, Locus of control, Atypicality, Anxiety, Social stress and Depression). The adjustment indices are based on the robust method, because the multivariate distribution was non-normal (Yuan, Lambert and Fouladi's standardized coefficient $=41.48$ ). The absence of normality is due mainly to two variables: Personal relations (asymmetry $=-2.62$ and kurtosis $=7.95$ ) and Self-esteem (asymmetry $=-2.25$ and kurtosis $=5.26$ ). With the Yuan-Bentler (2000) method the value of $\chi^{2}$ was reduced to 98 points, but the goodness of fit indices of the initial model remained unacceptable, $Y-B \chi^{2}(51$, $N=791)=357.6 ; R C F I=.86$; $R N N F I=.82 ; R I F I=.86 ; R M-$ $S E A=.087 ; C I=.079, .096 ; Y-B \chi^{2}$ $(51, N=791)=456.2 ; R C F I=.88$; $R N N F I=.84 ; R I F I=.88 ; R M-$ $S E A=.10 ; C I=.092, .11$.

The model of the original study and that of the Spanish adaptation were very similar (see Appendices 1 and 2), but three indicators contributed to two latent variables. These were depression (clinical maladjustment and personal adjustment), locus of control (school and clinical maladjustment) and sense of inadequacy (school and clinical maladjustment). Moreover, in the Spanish adaptation the Social stress scale was an indicator of the latent factor Personal adjustment, whilst the model of the original study included a correlation between the Social stress and Interpersonal relations scales. On the other hand, in the Spanish adaptation Relations with parents was an observable variable corresponding to the latent variables Personal adjustment and School maladjustment. In the present study the model of the Spanish adaptation showed a fairly acceptable fit according to the Bentler (2006) criteria: $Y-B \chi^{2}(46, N=791)=218.5$; $R C F I=.92 ; R N N F I=.89$; $R I F I=.92 ; R M S E A=.069 ; C I=.06$, $.078 ; \chi^{2}(46, N=791)=276.9$; $C F I=.93 ; N N F I=.90 ; I F I=.93$; RMSEA $=.08 ; C I=.07, .09$. However, the model of the original study showed a somewhat better fit to the data of the Basque adaptation, $Y-B \chi^{2}$ $(47, N=791)=212.5 ; R C F I=.92$; RNNFI $=.89 ; R I F I=.92 ; R M-$ $S E A=.067 ; C I=.058, .076 ; \chi^{2}$ $(47, N=791)=262.4 ; C F I=.93$; NNFI $=.93 ;$ IFI $=.93 ; R M-$ $S E A=.076 ; C I=.067, .085$ (see Figure 2). The $\chi^{2} / d f$ quotient attains a value of 4.5 . Although some observable variables presented relatively low saturations $(<.30)$, these were significant, and it was decided to maintain them in the model to facilitate cross-cultural comparison.

The final model shown in figure 2 preserves the three-factor structure of the original version in English, and this is of considerable relevance at a theoretical level, since, the psychometric characteristics of the BASC having been tested, the results of the present study corroborate the strength of the original model. On the one hand, 


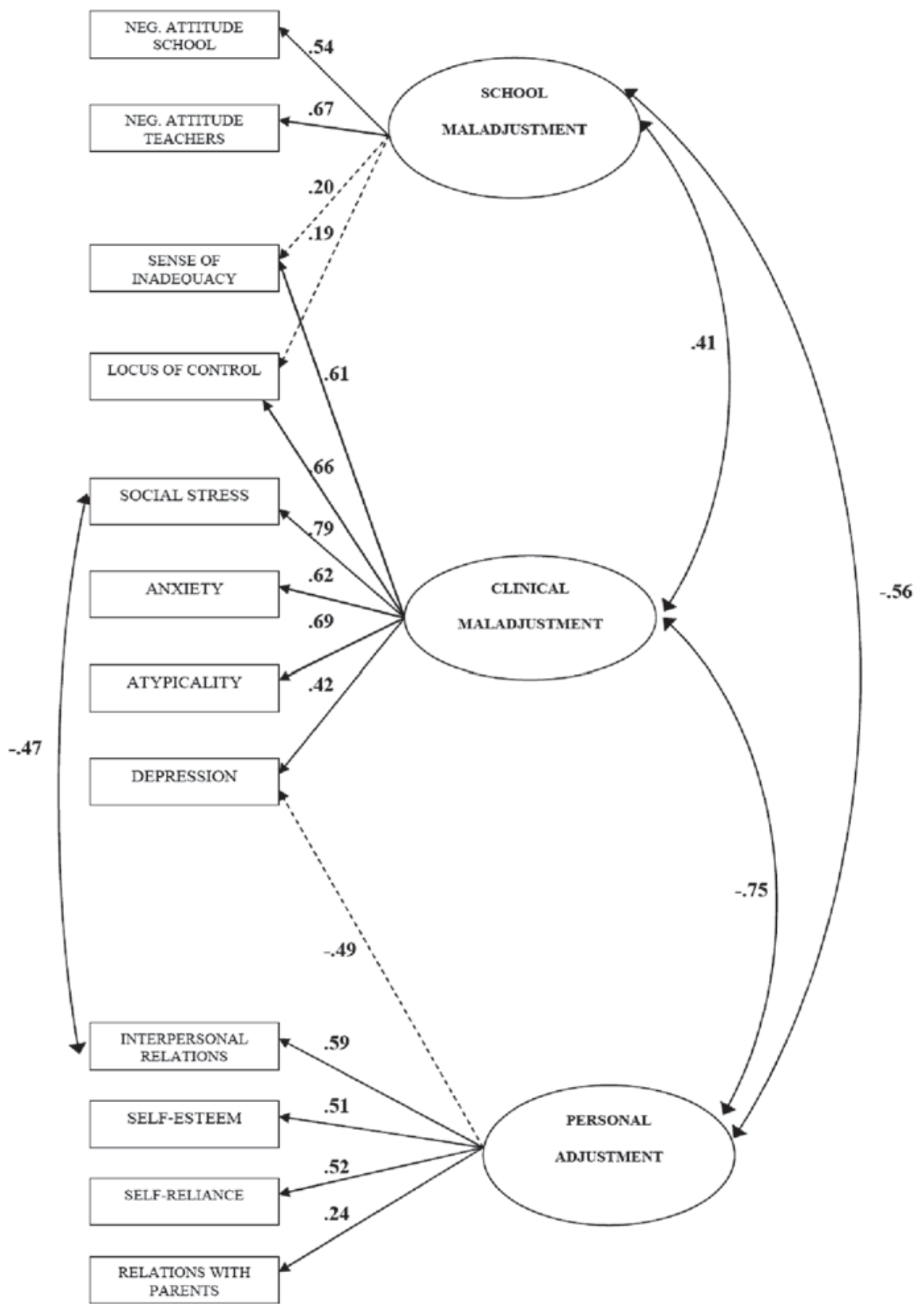

Figure 2. Final measurement model of the Basque adaptation of the BASC-S2 self-report. 
the exploratory factor analysis yielded a three-factor model with relatively high factor loadings and without cross-loadings in more than one factor. On the other, the confirmatory factor analysis verified the fit/adequacy of the model, insofar as the factor loadings were significant and acceptable, in the same way as the goodness of fit indices were acceptable. As an exception, it should be mentioned that the Relations with parents scale presented a factor loading lower than .30 assigned to the Personal adjustment factor.

\section{Internal consistency}

As regards the global dimensions, the reliability analyses revealed good internal consistency of clinical maladjustment ( $\alpha=.92)$, personal adjustment $(\alpha=.80)$, school maladjustment $(\alpha=.79)$ and emotional symptoms $(\alpha=.84)$, since they fulfilled Nunally's (1978) criterion of $\alpha \geq .70$ for considering adequate reliability.

Table 3 shows the alpha coefficients for this study and those obtained in the study with the Spanish adaptation. Greater variability was

Table 3

Comparison of the Internal Consistency of the Spanish Adaptation and the Basque Version of the BASC-S2

\begin{tabular}{lcc}
\hline \multirow{2}{*}{ Scale } & \multicolumn{2}{c}{ Cronbach's $\alpha$} \\
\cline { 2 - 3 } & This study & Spanish adaptation \\
\hline Negative attitude to school & .73 & .81 \\
Negative attitude to teachers & .50 & .71 \\
Anxiety & .83 & .81 \\
Atypicality & .77 & .79 \\
Locus of control & .71 & .77 \\
Social stress & .71 & .72 \\
Depression & .72 & .83 \\
Sense of inadequacy & .62 & .72 \\
Interpersonal relations & .64 & .83 \\
Relations with parents & .32 & .56 \\
Self-esteem & .67 & .75 \\
Self-reliance & .55 & .61 \\
\hline Median & .69 & .76 \\
\hline
\end{tabular}


found in the reliability of the scales than in the global dimensions. On average, internal consistency of the scales was around .69, ranging from .32 (Relations with parents) to .83 (Anxiety). The low reliability obtained in the Relations with parents scale is noteworthy. In the study of the Spanish adaptation of the S2 this scale was that with the lowest alpha coefficient $(\alpha=.54)$, but in the Basque adaptation the reliability index was so low that it was inadvisable to use this scale in specific way. The discrimination index for all the items on this scale is acceptable $(D I>.30)$, and the alpha coefficient does not improve if any item is removed from the scale.

\section{Evidence of concurrent validity}

In order to assess the concurrent validity of the Basque version of the BASC it was decided to include the Children's Depression Scale (CDS, Lang \& Tisher,
1983), since it is widely used by professionals and has been adapted to the Basque language (e.g., Balluerka, Gorostiaga, \& Haranburu, under review). Although the majority of the CDS scales do not have a clear parallel scale in the S2, the correlations analysis yields some interesting results. First of all, the general dimensions of the BASC correlate with those of the CDS, together with three specific scales: depression, self-esteem and social problems (see table 4). It should be pointed out that the score in the Total Positive dimension is of an inverse nature, so that the higher the score on this scale, the more these feelings are lacking. In the manual, this factor is referred to as sadness. As regards self-esteem, the CDS measures children's negative feelings, concepts and attitudes in relation to their own self-esteem and self-respect, whilst in the BASC this item refers to positive self-esteem.

In general, the self-esteem of the CDS is moderately associated

Table 4

Correlations Between the BASC-S2 and the CDS scales

\begin{tabular}{lcccccc}
\hline \multirow{2}{*}{\multicolumn{1}{c}{ CDS }} & \multicolumn{6}{c}{ BASC } \\
\cline { 2 - 7 } & $\begin{array}{c}\text { Clinical } \\
\text { maladjustment }\end{array}$ & $\begin{array}{c}\text { Personal } \\
\text { adjustment }\end{array}$ & $\begin{array}{c}\text { Emotional } \\
\text { symptoms }\end{array}$ & Depression & $\begin{array}{c}\text { Self- } \\
\text { esteem }\end{array}$ & $\begin{array}{c}\text { Interpers. } \\
\text { relations }\end{array}$ \\
\hline Sadness & $.16^{* *}$ & $-.45^{* *}$ & $.28^{* *}$ & $.30^{* *}$ & $-.27^{* *}$ & $-.21^{* *}$ \\
Depression & $.66^{* *}$ & $-.39^{* *}$ & $.67^{* *}$ & $.57^{* *}$ & $-.30^{* *}$ & $-.37^{* *}$ \\
Self-esteem & $.57^{* *}$ & $-.39^{* *}$ & $.60^{* *}$ & $.50^{* *}$ & $-.33^{* *}$ & $-.33^{* *}$ \\
Social problems & $.16^{* *}$ & $-.41^{* *}$ & $.28^{* *}$ & $.30^{* *}$ & $-.27^{* *}$ & $-.44^{* *}$ \\
\hline
\end{tabular}


with all the BASC scales analyzed in this section. The results obtained indicate that the depression $(r=.57$, $p<.001)$, self-esteem $(r=-.33$, $p<.001)$ and social problems/interpersonal relations $(r=-.44$, $p<.001)$ scales of the BASC and CDS questionnaires present reasonable correlation. As far as the rest of the correlations are concerned, it should be pointed out that they are in the expected direction and involve those variables and constructs for which a theoretical association would be expected. The social problems scale of the CDS presented an inverse and significant association with personal adjustment in the BASC $(r=-.41)$. Finally, the analysis confirmed the importance of the variables sadness (Total positive) $(\beta=.21, p<.001)$ and depression (Total depressive) $(\beta=.53, p<.001)$ as predictor variables of depression, $R^{2}=.36, F(2$, 602) $=188.26, p<.001$.

\section{Discussion}

The first objective of this study was to examine the rate of school maladjustment, clinical maladjustment and emotional symptoms in a sample of schoolchildren from the Basque Country Autonomous Region and to analyze whether there were differences according to sex and age. Given that the sample is from the school context, it is of particular interest to analyze participants' levels of school maladjust- ment. It was found that $4.7 \%$ obtain a clinically significant score, while $10.8 \%$ are at risk. These data indicate that around $15 \%$ express some aversion toward the school context (negative attitude to teachers and to school), data that are inevitably linked to the positive association found between school maladjustment and clinical maladjustment or emotional symptoms: high levels of school maladjustment are related to high levels of clinical maladjustment and emotional symptoms such as depression and sadness. In relation to clinical maladjustment, the results show that about $20 \%$ of the sample present symptoms of clinical maladjustment $(4.2 \%$ severe symptomatology and $15.2 \%$ at risk). The percentages close to $20 \%$ coincide with the findings of previous studies on the issue (López-Soler et al., 2009; Romero et al., 2010), which indicate that this is a population requiring special attention, to avoid such symptoms becoming chronified. Moreover, $13 \%$ of the schoolchildren present emotional symptoms $(4.4 \%$ severe symptomatology and $8.7 \%$ at risk).

In the present study boys show higher school maladjustment than girls, in line with the findings of Essau et al. (2000). Thus, it would seem that boys express their emotional aversion more explicitly at school, so that their school maladjustment is more evident. The scientific literature confirms this, indicating that teachers tend to report higher levels of school malad- 
justment among boys than among girls (Baker, 2006; Cava, Buelga, Musitu, \& Murgui, 2010). Moreover, in this study we found a significant interaction between sex and age for emotional symptoms, which could explain the contradictory results found in previous research. That is, these results indicate that on studying emotional symptoms in childhood it is important to take into account both sex and age of the children. Specifically, it was found that at age 12 girls presented more emotional symptomatology than boys, and this result has been partially confirmed by some studies indicating a greater tendency of girls to show emotional symptoms, of an anxious (Crijnen et al., 1999; Romero et al., 2010) or depressive nature as they approach adolescence (Angold et al., 2002).

The results of the present study confirm that sense of inadequacy and external locus of control are risk factors for school maladjustment, while good relations with parents and self-reliance are protective factors. People with external locus of control use more strategies focused on emotion and fewer problem-centred strategies than people with internal locus of control (Terry, 1994), because they believe their efforts will not be effective for influencing the result of a particular situation (Lazarus \& Folkman, 1984). Therefore, parents' and teachers' task would be to make students feel that they are competent and play an active part in their learning, so as to foster better personal, social and school adjustment.

The present study also sets a second objective: the adaptation to the Basque language (euskara) of the BASC (S2) questionnaire. Confirmatory factor analyses confirmed the validity of the scale in this population, as well as testing the model endorsed by the instrument's authors, which had shown adequate fit. The results indicate that the Basque version has a threefactor structure like the original version of the instrument and the Spanish version: school maladjustment (negative attitude to school, negative attitude to teachers, sense of inadequacy and locus of control), clinical maladjustment (sense of inadequacy, locus of control, social stress, anxiety, depression and atypicality) and personal adjustment (depression, interpersonal relations, self-esteem, self-reliance and relations with parents). Some variables have factor loadings in two latent factors as in the original study. For example, locus of control and sense of inadequacy belong to both school maladjustment and clinical maladjustment. On the other hand, depression is in both the clinical maladjustment and personal adjustment dimensions.

As regards the reliability of the instrument, the general dimensions of the BASC (school maladjustment, clinical maladjustment, personal adjustment and emotional symptoms) show adequate internal consistency. As for the reliability 
of the scales, this was acceptable in general, though with some exceptions, such as the Relations with parents scale which, as in the Spanish version, obtained a lower reliability index. Future research should examine this scale and its items in detail, to obtain a better definition of it, omitting some items or substituting them by more culturally appropriate ones. Furthermore, evidence was obtained of the BASC's concurrent validity. As was to be expected, the depression, self-esteem and interpersonal relations dimensions of the BASC show a moderate and significant relation with the corresponding dimensions of the CDS.

In sum, the self-report BASC for children aged 8 to 12 in its Basque version presents psychometric characteristics similar to those of the Spanish version, offering sufficient guarantees for its use as an instrument for assessing childhood disorders in the Basque-speaking population. It thus provides a tool for the evaluation of emotional, so- cial relations and behavior problems in conjunction or separately, taking into account a series of indicators that have shown their validity in the Basque version. The results obtained with this instrument can facilitate the identification of risk factors, as well as being of help in the design, planning, implementation and assessment of early detection/ attention measures.

The main limitation of this study concerns the participants selected, since they form part of a convenience sample from the Basque Country. In future research it will be possible to replicate the results from this study using samples from clinical contexts. Likewise, it would be interesting to analyze the temporal stability of the BASC-S2 (testretest reliability) and to adapt to the Basque-speaking population the remaining levels of the instrument (3-6 years and 12-18 years), both in the self-report format and as questionnaires for parents and homeroom teachers.

\section{References}

Aláez, M., Martínez-Arias, R., \& Rodríguez-Sutil, C. (2000). Prevalencia de trastornos psicológicos en niños y adolescentes, su relación con la edad y el género. Psicothema, 12, 525-532.
American Educational Research Association (AERA), American Psychological Association (APA) \& National Council on Measurement in Education (NCME) (1999). Standards for Educational and Psychological Test- 
ing. Washington DC: American Psychological Association.

American Psychiatric Association, APA. (2002). Manual Diagnóstico y Estadístico de los Trastornos Mentales (cuarta edición, texto revisado). Barcelona: Masson.

Angold, A., Costello, E., \& Worthman, C. (1998). Puberty and depression: The roles of age, pubertal status and pubertal timing. Psychological Medicine, 28, 51-61.

Angold, A., Erkanli, A., Farmer, E. M. Z., Fairbank, J. A., Burns, B. J., Keeler, G., \& Costello, E. J. (2002). Psychiatric disorder, impairment, and service use in rural African American and White youth. Archives of General Psychiatry, 59, 893-901. doi: 10.1001/archpsyc.59.10.893.

Angold, A., Erkanli, A., Silberg, J., Eaves, L., \& Costello, E. J. (2002). Depression scale scores in 8-17-yearolds: Effects of age and gender. Journal of Child Psychology and Psychiatry, 43, 1052-63. doi: 10.1111/1469-7610.00232.

Arbuckle, J. L. (1996). Full information estimation in the presence of incomplete data. In G.A. Marcoulides \& R.E. Schumacker (Eds.), Advanced structural equation modeling: Issues and techniques (pp. 243-277). Mahwah, NJ: Lawrence Erlbaum Associates.

Axelson, D. A., \& Birmaher, B. (2001). Relation between anxiety and depressive disorders in childhood and adolescence. Depression and Anxiety, 14, 67-78. doi: 10.1002/ da. 1048.

Balluerka, N., Gorostiaga, A., \& Haranburu, M. (in review). Validación del CDS (Escala de Depresión Infantil) en población vascoparlante. The Spanish Journal of Psychology.
Baker, J. A. (2006). Contributions of teacher-child relationships to positive school adjustment during elementary school. Journal of School Psychology, 44, 211-229. doi: 10.1016/ j.jsp.2006.02.002.

Bentler, P. M. (2006). EQS, Structural Equations Program Manual. Encino, CA: Multivariate Statistical Software, Inc.

Bollen, K. A. (1989). Structural equations with latent variables. Wiley Series in Probability and Mathematical Statistics. New York: Wiley.

Bragado, C., Carrasco, I., Sánchez, M. L., \& Bersabé, R. M. (1996). Trastornos de ansiedad en escolares de 6 a 17 años. Ansiedad y Estrés, 2, 97112.

Cancio, E. J., West, R. P., \& Young, K. R. (2004). Improving mathematics homework completion and accuracy of students with EBD through self-management and parent participation. Journal of Emotional and Behavioral Disorders, 12, 9-22. doi: 10.1177/10634266040120010201.

Carney, A. G., \& Merrell, K. W. (2002). Reliability and comparability of a Spanish-language form of the preschool and kindergarten behaviour scales. Psychology in the Schools, 39, 367-373. doi: 10.1002/pits.10033.

Cava, M. J., Buelga, S., Musitu, G., \& Murgui, S. (2010). Violencia escolar entre adolescentes y sus implicaciones en el ajuste psicosocial: un estudio longitudinal. Revista de Psicodidáctica, 15, 21-34.

Cole, D. A. (1991). Preliminary support for a competency-based model of depression in children. Journal of $A b$ normal Psychology, 100, 181-190. doi: 10.1037/0021-843X.100.2.181.

Crijnen, A., Achenbach, T., \& Verhulst, F. (1999). Problems reported by par- 
ents Syndrome Constructs. American Journal of Psychiatry, 156, 569574.

Cronbach, L. J. (1951). Coefficient alpha and the internal structure of the test. Psychometrika, 16, 297-334.

Del Barrio, V. (1995). Evaluación clínica infantil y adolescente. In F. Silva (ed.). Evaluación psicológica en niños y adolescentes (pp. 461-530). Madrid: Síntesis Psicológica.

Del Barrio, V. (2000). La depresión infantil. Factores de riesgo y posibles soluciones. Málaga: Aljibe.

Del Barrio, V. (2010). La depresión infantil a la altura de nuestro tiempo. Información Psicológica, 100, 49-59.

Denham, S. A. (2006). Social-emotional competence as support for school readiness: What it is and how do we assess it? Early Education and Development, 17, 57-89. doi: 10.1207/ s15566935eed1701_4.

Escobar, M., Trianes, M. V., FernándezBaena, F. J., \& Miranda, J. (2010). Relaciones entre Aceptación Sociométrica Escolar e Inadaptación Socioemocional, Estrés Cotidiano y Afrontamiento. Revista Latinoamericana de Psicología, 42, 469-479.

Escobar, M., Fernández-Baena, F. J., Miranda, J., Trianes, M. V., \& Cowie, H. (2011). Baja aceptación de los iguales e inadaptación emocional/conductual en escolares: Efectos del estrés cotidiano, afrontamiento y sexo. Anales de Psicología, 27, 412-417.

Essau, C. A., Conradt, J., \& Petermann, F. (2000). Frequency, comorbidity, and psychosocial impairment of depressive disorders in adolescents. Journal of Adolescent Research, 15, 470-481. doi: 10.1177/0743558400154003.

EUSTAT, Instituto de Estadística de Euskadi (2011). http://www.eustat.es/bancopx/spanish/Sociedad/
Educación/Enseñanza/Actividad\%20 educativa/Actividad\%20educativa. html\#axzz1T16v32kD

Ferguson, D. M., \& Woodward, L. J. (2002). Mental health, educational and social role outcomes of adolescents with depression. Archives of General Psychiatry, 59, 225-231. doi: 10.1001/archpsyc.59.3.225.

Field, A. (2005). Discovering statistics using SPSS (2. ${ }^{\mathrm{a}}$ ed.). Thousand Oaks, CA: Sage.

Fleming, J. E., \& Offord, D. R. (1990). Epidemiology of childhood depressive disorders: A critical review. Journal of the American Academy of Child and Adolescent Psychiatry, 29, 571-580. doi: 10.1097/00004583199007000-00010.

González, J., Fernández, S., Pérez, E., \& Santamaría, P. (2004). Adaptación española del sistema de evaluación de la conducta en niños y adolescentes: BASC. Madrid: TEA.

Hambleton, R. K., \& Patsula, L. (1999). Increasing the validity of adapted tests: Myths to be avoided and guidelines for improving test adaptation practices. Journal of Applied Testing Technology, 1, 1-30.

Harden, B. J., Winslow, M. B., Kendziora, K. T., Shahinfar, A., Rubin, K. H., Fox, N. A., et al. (2000). Externalizing problems in Head Start children: An ecological exploration. Early Education \& Development. Special Issue: Mental Health and Head Start, 11, 357-385.

Herman, K. C., Lambert, S., Reinke, W. M., \& Ialongo, N. (2008). Low academic competence in first grade as a risk factor for depressive cognitions and symptoms in middle school. Journal of Counselling Psychology, 55, 400-410. doi: 10.1037/ a0012654. 
Holmbeck, G. N., Welborn, A., Bachanas, P., Garber, J., Bearman, K., Abad, M., et al. (2008). Evidence-based assessment in pediatric psychology: measures of psychological adjustment and psychopathology. Journal of Pediatric Psychology, 33, 958-980. doi: 10.1093/jpepsy/jsm059.

Hu, L., \& Bentler, P. M. (1999). Cutoff criteria for fit indexes in covariance structure analysis: Conventional criteria versus new alternatives. Structural Equation Modeling, 6, 1-55. doi: 10.1080/10705519909540118.

Jamshidian, M., \& Bentler, P. M. (1998). A quasi-Newton method for minimum trace factor analysis. Journal of Statistical Computation and Simulation, 62, 73-89. doi: 10.1080/00949659808811925.

Keane, S. P., \& Calkins, S. D., (2004). Predicting kindergarten peer social status from toddler and preschool problem behavior. Journal of Abnormal Child Psychology, 32, 409-423. doi: 10.1023/B:JACP.0000030294. 11443.41 .

Kovacs, M., Feinberg, T. L., CrouseNovak, M. A., Paulauskas, S. L., \& Finkelstein, R. (1984). Depressive disorders in childhood. I. A longitudinal prospective study of characteristics and recovery. Archives of General Psychiatry, 41, 229-237. doi: 10.1001/ archpsyc. 1984.01790140019002.

Kovacs, M. (2010). Prodromal symptoms and atypical affectivity as predictors of major depression in juveniles: Implications for prevention. Journal of Child Psychology and Psychiatry, 51, 472-496. doi: 10.1111/j.14697610.2010.02230.x.

Lacalle, M. (2009). Escalas DSM del CBCL y YSR en niños y adolescentes que acuden a consulta en servicios de salud mental. (Doctoral thesis. Faculty of Psychology. Universidad Autónoma of Barcelona).

Lang M., \& Tisher M. (1983). Children's Depression Scale, second research edition. Camberbell, Victoria, Australia: Australian Council for Educational Research.

Lazarus, R., \& Folkman, S. (1986). Estrés y procesos cognitivos. Barcelona: Martínez Roca.

Lei, M., \& Lomax, R. G. (2005). The effect of varying degrees of nonnormality in structural equation modeling. Structural Equation Modeling: A Multidisciplinary Journal, 12, 1-27. doi: 10.1207/s15328007sem1201_1.

López-Soler, C., Castro, M., Alcántara, M., Fernández, V., \& López Pina J.A. (2009). Prevalencia y características de los síntomas externalizantes en la infancia. Diferencias de género. Psicothema, 21, 353-358.

Nunnally, J. C. (1978). Psychometric theory. ( $2^{\text {nd }}$ Edition). New York: McGraw-Hill.

Olson, S. L., \& Hoza, B. (1993). Preschool developmental antecedents of conduct problems in children beginning school. Journal of Clinical Child Psychology, 22, 60-67. doi: 10.1207/s15374424jccp2201_6.

Patterson, G. R., \& Stoolmiller, M. (1991). Replications of a dual failure model for boys' depressed mood. Journal of Consulting and Clinical Psychology, 59, 491-498. doi: 10.1037/0022-006X.59.4.491.

Reddy, L. A., \& Richardson, L. (2006). School-based prevention and intervention programs for children with emotional disturbance. Education and Treatment of Children, 29, 1-26.

Reinherz, H. Z., Giaconia, R. M., Carmola Hauf, A. M., Wasserman, 
M. S., \& Paradis, A. D. (2000). General and specific childhood risk factors for depression and drug disorders by early adulthood. Journal of the American Academy of Child and Adolescent Psychiatry, 39, 223-231. doi: 10.1097/00004583-20000200000023.

Reynolds, C. R., \& Kamphaus, R. W. (1992). Behavior assessment system for children (BASC). Circle Pines, MN: American Guidance Services.

Roeser, R. W., Van der Wolf, K., \& Strobel, K. R. (2001). On the relation between social-emotional and school functioning during early adolescence. Preliminary findings from Dutch and American samples. Journal of School Psychology, 39, 111-139. doi: 10.1016/S0022-4405(01)00060-7.

Romero, K., Canals, J., Hernández-Martínez, C., Jané, M.C., Viñas, F., \& Domènech-Llaberia, E. (2010). Comorbilidad entre los factores de ansiedad del SCARED y la sintoma- tología depresiva en niños de 8-12 años. Psicothema, 22, 616-618.

Terry, D. (1994). Determinants of coping: The role of stable and situational factor. Journal of Personality and Social Psychology, 66, 895-910. doi: 10.1037/0022-3514.66.5.895.

Twenge, J. M., Gentile, B., DeWall, C. N., Ma, D., Lacefield, K., \& Schurtz, D. R. (2010). Birth cohort increases in psychopathology among young Americans, 1938-2007: A cross-temporal meta-analysis of the MMPI. Clinical Psychology Review, 30, 145154. doi: 10.1016/j.cpr.2009.10.005.

World Health Organization, WHO (1992). CIE-10. Trastornos mentales y del comportamiento. Madrid: Meditor.

Yuan, K. H., \& Bentler, P. M. (2000). Three likelihood-based methods for mean and covariance structure analysis with non normal missing data. En Sociological Methodology 2000 (pp. 165-200). Washington, DC: American Sociological Association. 
Joana Jaureguizar Albonigamayor is an Associate Professor in the Department of Developmental Psychology and Education at the School of Educational Sciences (University of the Basque Country). Her research work has been focused on the study of conflictive behavior in children and adolescents and their family relations. The latest research project in which she participated involved the analysis of child depression in schools in the Basque Country.

Elena Bernaras Iturrioz is a Full Professor in the Department of Developmental Psychology and Education at the School of Educational Sciences (University of the Basque Country). Her research focuses on Special Education, and in particular on visual disabilities and the analysis of good practice in university teaching. She is currently working on the analysis of depressive symptoms in school contexts and their prevention.

Izaskun Ibabe Erostarbe is a Full Professor in the Department of Social Psychology and Behavior Sciences Methodology at the Psychology Faculty of the University of the Basque Country. She has extensive teaching experience in relation to research methods in the social sciences. Her research background is particularly strong in risk and protective factors for adolescents' violent behaviors in the family and school contexts. Currently, her research activity is focused on the study of the relation between depressive symptomatology and social relations in children from the general population.

Marta Sarasa Maia is an Assistant Professor in the Department of Developmental Psychology and Education at the School of Educational Sciences (University of the Basque Country). She has extensive professional experience in various schools in the Basque Country, where her specialty field has been Inclusive Education, with particular emphasis on special educational needs. A concrete aspect on which her work has focused is children with autism and generalized developmental disorders and their families. She is currently working on her doctoral dissertation and is involved in research on child depression in the school context. 


\section{Appendix 1}

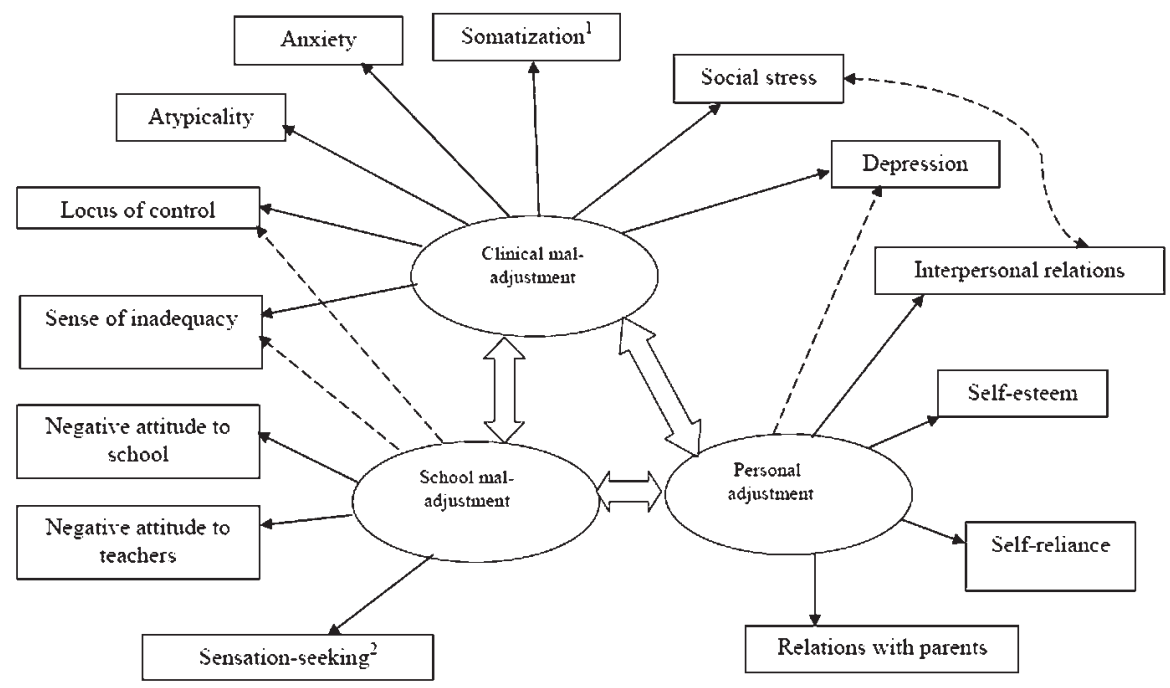

Note: ${ }^{1}$ and ${ }^{2}$ are variables corresponding to the BASC-S3 instrument, but are not included in the BASC-S2.

Figure 3. Final model of the BASC in the original studies. 


\section{Appendix 2}

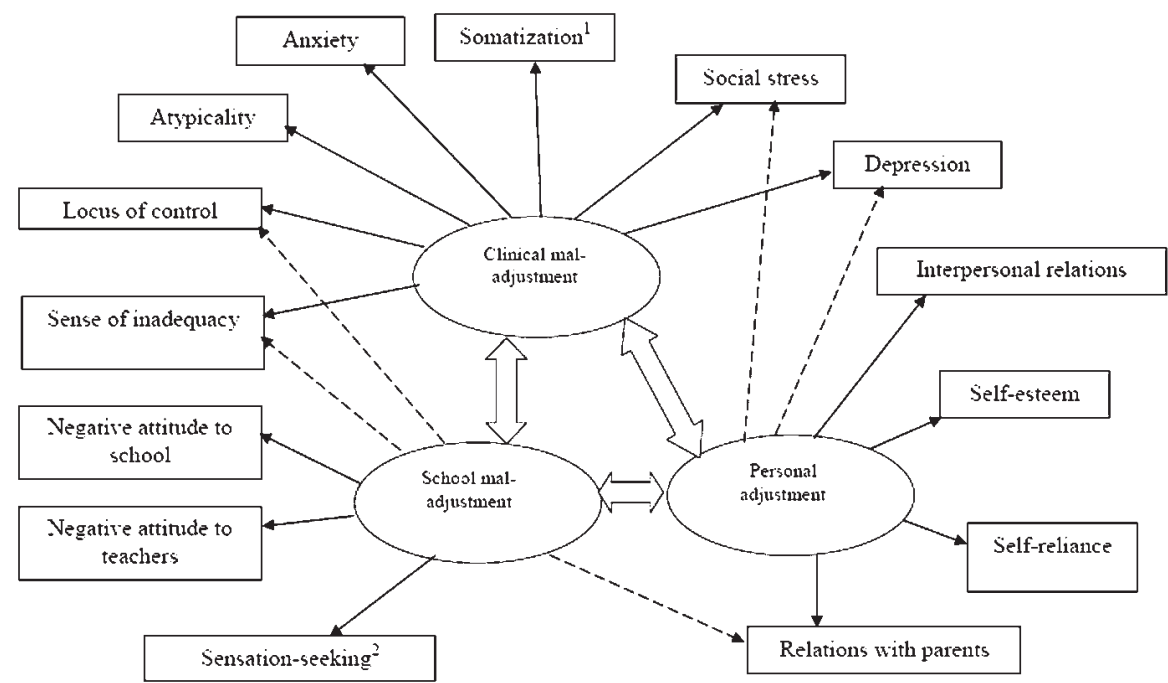

Note: ${ }^{1}$ and ${ }^{2}$ are variables corresponding to the BASC-S3 instrument, but are not included in the BASC-S2.

Figure 4. Final model of the BASC in the Spanish adaptation. 


\title{
Desajuste escolar, clínico y emocional en escolares de 8 a 12 años: adaptación del Behavior Assessment System for Children en su versión de Autoinforme (BASC-S2) a la población vascoparlante*
}

\author{
Joana Jaureguizar, Elena Bernaras, Izaskun Ibabe, y Marta Sarasa \\ $\mathrm{UPV} / \mathrm{EHU}$
}

\begin{abstract}
Resumen
Los trastornos emocionales influyen en el ajuste escolar del alumnado, pero la identificación de estos niños presenta muchos déficits. De ahí la necesidad de contar con herramientas diagnósticas fiables y válidas. Este estudio tiene un doble objetivo: estudiar la tasa de desajuste escolar, desajuste clínico y síntomas emocionales en función del sexo y la edad; y la adaptación al euskara y la consiguiente validación del Behavior Assessment System for Children (BASC) en su versión de autoinforme para alumnado de 8 a 12 años (S2). Han participado 795 estudiantes de siete centros escolares de la Comunidad Autónoma Vasca. El 15\% de los escolares presenta síntomas de desajuste escolar, siendo el nivel de los varones mayor que el de las niñas. El 13\% de los escolares también presenta síntomas emocionales, especialmente presentes en las niñas de 12 años. La versión vasca del BASC-S2, por su parte, presenta características psicométricas adecuadas.
\end{abstract}

Palabras clave: Ajuste escolar, síntomas emocionales, adaptación, validación, euskara.

Abstract

Emotional disorders influence pupils' school adjustment, but there are some serious deficiencies as regards the identification of the children in question. Hence the need for reliable and valid diagnostic tools. The objectives of this study are twofold: to study the rates of school maladjustment, clinical maladjustment and emotional symptoms according to sex and age; and to adapt to the Basque language (euskara) and subsequently validate the Behavior Assessment System for Children (BASC), in its selfreport version for pupils aged 8 to 12 years (S2). Participants were 795 pupils from seven schools in the Basque Country Autonomous Region. Fifteen per cent of the pupils presented school maladjustment, the rate in boys being higher than in girls. Thirteen per cent also presented emotional symptoms, which were especially detected in 12-year-old girls. As regards the Basque version of the BASC-S2, its psychometric properties were found to be adequate.

Keywords: School adjustment, emotional symptoms, adaptation, validation, Basque (euskara).

Correspondencia: Joana Jaureguizar. Dpto. de Psicología Evolutiva y de la Educación. Universidad del País Vasco-Euskal Herriko Unibertsitatea. EU Magisterio de Bilbao. Barrio Sarriena s/n. Leioa (Bizkaia), Spain. E-mail: joana.jauregizar@ehu.es

* Este trabajo ha sido financiado por el Gobierno Vasco (AE-2010-1-22) y la Universidad del País Vasco/Euskal Herriko Unibertsitatea (UPV/EHU) UFI 11/04. 


\section{Introducción}

La evaluación temprana de problemas emocionales y de conducta en la etapa escolar es uno de los objetivos prioritarios de la investigación en salud mental infantojuvenil, ya que ello permitiría desarrollar una adecuada intervención y prevenir futuros trastornos en la etapa adolescente y adulta. Sin embargo, en especial los niños con trastornos emocionales son una de las poblaciones cuya identificación y tratamiento presenta más déficits (Reddy y Richardson, 2006). Existen algunos estudios con muestras clínicas y escolares españolas que han analizado las categorías diagnósticas con mayor prevalencia en la población infanto-juvenil (Aláez, Martínez-Arias, y Rodríguez-Sutil, 2000; Bragado, Carrasco, Sánchez, y Bersabe, 1996; López-Soler, Castro, Alcántara, Fernández, y López Pina, 2009; Romero et al., 2010). Normalmente estos estudios se realizan con muestras de diferentes rangos de edad e instrumentos de medición muy diferentes, lo cual obliga a tener cierta precaución en el momento de generalizar los resultados. En los estudios con muestras clínicas las categorías diagnósticas de mayor prevalencia son los trastornos de ansiedad (rango del $13.3-41.16 \%$ ), seguido de los trastornos de conducta (rango del 18.1$34.25 \%$ ) y finalmente aparecen los trastornos depresivos (rango del 9.94-14.6) (Aláez et al., 2000; Bragado et al., 1996; López-Soler et al., 2009). Sin embargo, si tomamos en cuenta estudios recientes realizados con muestras escolares de 6 a 12 años (Romero et al., 2010), se observa que las cifras de los trastornos de ansiedad se disparan hasta un $47 \%$ y los de depresión se sitúan entre un $9.07 \%$ y un $11.5 \%$, en función de la prueba utilizada. Estudios internacionales, como el meta-análisis de Twenge, Gentile, DeWall, Ma, Lacefield y Schurtz (2010) en el que se realiza una comparación con cohortes a lo largo de los años 1938-2007, evidencian un aumento de la psicopatología (como los trastornos ansiosos y depresivos) en jóvenes estudiantes.

Tradicionalmente los estudios de prevalencia de los trastornos emocionales y de conducta suelen prestar especial atención a las diferencias en función de la edad y el sexo (Aláez et al., 2000), aunque las investigaciones han evidenciado que los resultados son contradictorios. Algunos estudios internacionales indican una mayor tendencia de las niñas a presentar sintomatología emocional, en particular de tipo ansioso (Axelson y Birmaher, 2001; Crijnen, Achenbach, y Verhuslt, 1999) o depresivo a medida que se acercan a la adolescencia (Angold, Erkanli, Silberg, Eaves, y Costello, 2002), mientras que otros estudios muestran tasas de problemas emocionales (ansiedad y depresión particularmente) similares entre niños y niñas menores de 14 años (Essau, Conradt, y Petermann, 2000), 
e incluso tasas mayores de trastornos depresivos en los niños varones (Angold, Costello, y Worthman, 1998). También se han encontrado diferencias de sexo en relación a los predictores de la depresión infantil. Así, en niños la ansiedad por sí sola es una buena predictora, mientras que en las niñas los predictores de depresión son la ansiedad, la preocupación y la hipersensibilidad (Kovacs, 2010). La edad es otra variable que debe tenerse muy presente ya que, por ejemplo, el comienzo de los trastornos depresivos mayores suele producirse entre los $11 \mathrm{y}$ los 12 años de edad, aunque el inicio de la sintomatología depresiva menos severa se observa principalmente hacia los 7 y los 8 años (Del Barrio, 2000).

De acuerdo con estudios previos, los problemas de adaptación escolar están asociados tanto a trastornos emocionales como a trastornos de conducta (Denham, 2006; Fleming y Offord, 1990; Herman, Lambert, Ialongo, y Ostrander, 2008; Olson y Hoza, 1993). Los niños con síntomas depresivos difícilmente pueden concentrarse en sus estudios y les resulta difícil obtener unas buenas calificaciones (Cole, 1991; Patterson y Stoolmiller, 1991; Roeser, van der Wolf, y Strobel, 2001), o realizar las tareas escolares (Cancio, West, y Young, 2004), aumentando este hecho su sentido de incapacidad tanto social como académico (autoconcepto académico negativo). Los estudiantes perciben que poco pueden hacer para mejo- rar su rendimiento académico (locus de control externo), lo que incrementa su sintomatología depresiva. No obstante, también es cierto que el bajo rendimiento escolar constituye un factor de riesgo para sufrir depresión (Herman et al., 2008), ya que el desempeño académico pobre alimenta el autoconcepto negativo que el niño va forjándose como estudiante en sus años escolares, haciendo mella en la confianza en sí mismo como estudiante. Por lo tanto, la adecuada detección de este tipo de trastornos - a través de sistemas de evaluación amplios, que abarquen varias dimensiones diagnósticas - y la formación de los diferentes profesionales que se relacionan con el niño (psicólogos escolares y profesores), serán esenciales para favorecer el adecuado ajuste personal y escolar de los estudiantes.

Las clasificaciones nosológicas más utilizadas para el diagnóstico de trastornos psicológicos en general podrían clasificarse en dos grandes modelos: el modelo médico-categorial y el modelo psicométrico dimensional. El modelo médico-categorial, como el DSMIV-TR (American Psychiatric Association, APA, 2002) o el CIE-10 (Organización Mundial de la Salud, OMS, 1992), emplea criterios cualitativos y subjetivos para establecer la presencia de trastornos, entiende los trastornos mentales como entidades discretas y utiliza básicamente la entrevista para llegar a un diagnóstico (Del Barrio, 
1995; Lacalle, 2009). En el ámbito infanto-juvenil está cobrando más relevancia el modelo psicométrico dimensional, que utiliza procedimientos cuantitativos para determinar empíricamente qué características tienden a co-ocurrir en las diferentes formas de síndromes, llegando a una valoración del grado de intensidad del problema (Lacalle, 2009). Uno de los instrumentos que se enmarcan dentro de este modelo dimensional y que es ampliamente utilizado en el ámbito clínico y escolar es el Sistema de Evaluación de la Conducta de Niños y Adolescentes (BASC) de Reynolds y Kamphaus (1992), ya que permite llegar a una evaluación integrada y no parcial (Carney y Merrell, 2002). Holmbeck et al. (2008) señalan como puntos fuertes del BASC el hecho de que ofrece la «Historia estructurada de desarrollo», un «Sistema de observación del estudiante», varias subescalas que no contemplan otras pruebas (como autoestima, confianza en sí mismo, locus de control, sentido de incapacidad, etc.) y toda una serie de índices de validez (Índice F, una medida de la tendencia a responder de una forma excesivamente negativa sobre sus propias percepciones y emociones; Indice V, una medida básica de la validez general de las puntuaciones del cuestionario; Índice ICR, de consistencia interna de las respuestas; y el Índice PTR de patrón de respuestas). Las escalas globales de este instrumento se han utilizado en recientes inves- tigaciones sobre psicopatología e inadaptación (Escobar, FernándezBaena, Miranda, Trianes, y Cowie, 2011; Escobar, Trianes, FernándezBaena, y Miranda, 2010; Keane y Calkins, 2004).

Una de las escalas más relevantes que contempla el BASC es el diagnóstico de sintomatología depresiva (Del Barrio, 2010). Dado el temprano inicio de la sintomatología depresiva (Ferguson y Woodward, 2002; Kovacs, Feinberg, CrouseNovak, Paulauskas, y Finkelstein, 1984; Reinherz, Giaconia, Carmola, Wasserman, y Paradis, 2000), la detección precoz cobra especial relevancia. Por lo tanto, resulta de gran utilidad contar con instrumentos de cribado que aporten información sobre la sintomatología depresiva y además, sobre otras muchas dimensiones emocionales y conductuales del niño o adolescente.

Teniendo en cuenta todo lo anterior, este estudio ha tenido como objetivo principal estudiar la tasa de desajuste escolar, desajuste clínico y síntomas emocionales en una muestra de escolares de la Comunidad Autónoma Vasca y analizar si existen diferencias en función del sexo y la edad. Partiendo de la realidad lingüística de la Comunidad Autónoma Vasca - según los datos del Instituto Vasco de Estadística (EUSTAT, 2011), el 91,19\% de los estudiantes de Educación Primaria estudian en el modelo D (exclusivamente en euskara) o B (bilingüe euskara-castellano) - del estudio ha surgido un segundo objetivo: la adaptación al 
euskara y la consiguiente validación del BASC en su versión de autoinforme para alumnado de 8 a 12 años (S2). Ello ha implicado verificar si la estructura factorial de este instrumento corresponde a la del modelo original y a la del modelo de la adaptación española de tres factores (ajuste personal, desajuste clínico y escolar) (ver Anexos 1 y 2) a través de dos estrategias de análisis: análisis exploratorio y análisis confirmatorio. Asimismo, se ha pretendido evaluar la consistencia interna (alpha de Cronbach) del instrumento, y proporcionar datos sobre la validez concurrente.

\section{Método}

\section{Participantes}

En este estudio participaron 795 niños y niñas (47\% niños) de edades comprendidas entre 8 y 12 años $(M=9.65 ; D T=1.2)$ pertenecientes a siete centros escolares de la de la Comunidad Autónoma Vasca (cuatro centros públicos y tres centros concertados; tres centros de capitales de provincia, y otros cuatro de poblaciones grandes, medianas o pequeñas). La edad media de los niños era de 9.70 años mientras que la media de las niñas era de 9.58 años. El 25\% $(n=196)$ de los estudiantes cursaban $3 .^{\circ}$ de Educación Primaria, el 25\% $(n=199)$ estaba en $4 .^{\circ}$ curso, el $27 \%(n=217)$ en $5 .^{\circ}$ curso y el $23 \%(n=182)$ en 6. ${ }^{\circ}$ curso.

\section{Instrumentos de medida}

\author{
Sistema de Evaluación de \\ la Conducta de Niños y \\ Adolescentes (BASC, Reynolds \\ y Kamphaus, 1992)
}

El BASC es un sistema de evaluación multidimensional diseñado para la valoración de dimensiones tanto positivas (escalas adaptativas) como negativas (escalas clínicas) del comportamiento y de la personalidad del niño o adolescente. Además, proporciona información desde múltiples fuentes: autoinforme (S), familia $(\mathrm{P})$ y tutores $(\mathrm{T})$. Los cuestionarios son diferentes según la edad del sujeto evaluado: nivel 1 (3-6 años), nivel 2 (6-12 años) y nivel 3 (12-18 años). En el caso del Autoinforme (S), son dos los niveles de aplicación: niños de 6-12 años (S2) y adolescentes de 12-18 años (S3). Los componentes del BASC se pueden utilizar de forma aislada o en conjunto. En este estudio se administró solamente el autoinforme (S2) que consta de 146 enunciados y doce escalas, agrupadas en ocho escalas clínicas (ver cuadro 1) y cuatro escalas adaptativas (ver cuadro 2). Se optó por administrar un autoinforme a los participantes, ya que a diferencia de otros cuestionarios que pueden completar los tutores o los padres, el autoinforme registra lo que está pasando en el mundo interior del niño, obteniendo información rica sobre sus pensamientos, sentimientos, actitudes y reacciones internas ante su 
Cuadro 1

Escalas Clínicas del BASC-S2

\begin{tabular}{cl}
\hline \multicolumn{1}{c}{ Escala } & \multicolumn{1}{c}{ Definición } \\
\hline $\begin{array}{c}\text { Actitud negativa } \\
\text { hacia el colegio }\end{array}$ & $\begin{array}{l}\text { Sentimientos de alienación, hostilidad e insatisfacción respecto del } \\
\text { colegio. }\end{array}$ \\
\hline $\begin{array}{c}\text { Actitud negativa } \\
\text { hacia los profesores }\end{array}$ & $\begin{array}{l}\text { Sentimientos de antipatía hacia los profesores, creencias de que los } \\
\text { docentes son injustos, que no prestan la suficiente atención al alum- } \\
\text { nado, o que exigen demasiado. }\end{array}$ \\
\hline Atipicidad & $\begin{array}{l}\text { Tendencia a tener cambios bruscos de ánimo, ideas extrañas, expe- } \\
\text { riencias inusuales o pensamientos obsesivo-compulsivos y conduc- } \\
\text { tas que se consideran «raras». }\end{array}$ \\
\hline Locus de control & $\begin{array}{l}\text { Creencia de que los premios y castigos están controlados por even- } \\
\text { tos externos o por otras personas. }\end{array}$ \\
\hline Estrés social & $\begin{array}{l}\text { Nivel de estrés que experimentan los niños y adolescentes en sus } \\
\text { interacciones con los demás. }\end{array}$ \\
\hline Ansiedad & $\begin{array}{l}\text { Sentimientos de nerviosismo, preocupación, y miedo; tendencia a } \\
\text { sentirse desbordado por los problemas. }\end{array}$ \\
\hline Depresión & $\begin{array}{l}\text { Síntomas habituales de la depresión, incluyendo sentimientos de so- } \\
\text { ledad y tristeza e incapacidad para disfrutar de la vida. }\end{array}$ \\
\hline $\begin{array}{c}\text { Sentido de } \\
\text { incapacidad }\end{array}$ & $\begin{array}{l}\text { Percepciones de no tener éxito en la escuela, dificultad para conse- } \\
\text { guir los propios objetivos e incapacidad general. }\end{array}$ \\
\hline
\end{tabular}

Cuadro 2

Escalas Adaptativas del BASC-S2

\begin{tabular}{cl}
\hline Escala & \multicolumn{1}{c}{ Definición } \\
\hline $\begin{array}{c}\text { Relaciones } \\
\text { interpersonales }\end{array}$ & $\begin{array}{l}\text { Percepción de tener buenas relaciones sociales y amistades con sus } \\
\text { iguales. }\end{array}$ \\
\hline $\begin{array}{c}\text { Relaciones } \\
\text { con los padres }\end{array}$ & $\begin{array}{l}\text { Consideración positiva hacia los padres y sentimiento de que ellos } \\
\text { le estiman. }\end{array}$ \\
\hline Autoestima & Sentimientos de autoestima, autorrespeto y autoaceptación. \\
\hline $\begin{array}{c}\text { Confianza } \\
\text { en sí mismo }\end{array}$ & $\begin{array}{l}\text { Confianza en la propia capacidad para resolver problemas, creen- } \\
\text { cia propia independencia y en la capacidad de decidir por sí } \\
\text { mismo. }\end{array}$ \\
\hline
\end{tabular}


entorno (González, Fernández, Pérez, y Santamaría, 2004). La fiabilidad de las dimensiones globales del BASC S-2 de la adaptación española varía de .77 a .91 , con un valor promedio de .86 .

Las doce escalas definidas se agrupan en cuatro dimensiones globales: ajuste personal (que consta de las escalas de relaciones interpersonales, relaciones con los padres, confianza en sí mismo y autoestima), desajuste clínico (que comprende las escalas de ansiedad, atipicidad y locus de control), desajuste escolar (que consta de las escalas de actitud negativa hacia el colegio y actitud negativa hacia los profesores) e índice de síntomas emocionales. Éste último representa un indicador global de alteraciones emocionales, concretamente de problemas interiorizados. Consta de las escalas de ansiedad, relaciones interpersonales, autoestima, estrés social, depresión y sentido de incapacidad.

\section{Escala de depresión para niños (CDS; Lang y Tisher, 1983)}

En su versión en euskara (Balluerka, Gorostiaga, y Haranburu, en revisión). Este instrumento ha sido diseñado para ser administrado a niños y adolescentes entre 8 y 16 años. Está compuesto por 66 elementos que, en su mayoría, están formulados en sentido depresivo, afirmando una situación indicativa de este trastorno; el resto aluden a situaciones que no presentan contenido depre- sivo. Se obtienen dos grandes dimensiones - Total depresivo y Total positivo- y 8 subescalas - Respuesta Afectiva, Problemas Sociales, Autoestima, Preocupación por la muerte, Sentimientos de culpa, Depresivos Varios, Ánimo-Alegría y Positivos Varios (capacidad para experimentar alegría)-. Las primeras 6 subescalas (48 ítems) están agrupadas en una Puntuación Total Depresiva y las últimas 2 subescalas (18 ítems) en una Puntuación Total Positiva. La adaptación vasca de la prueba presenta una excelente consistencia interna para Total Depresivo $(\alpha=.95)$ y un nivel aceptable para Total Positivo $(\alpha=.75)$. Estos datos coinciden casi plenamente con los resultados de consistencia interna del presente estudio: $\alpha=.94$ para Total Depresivo y $\alpha=.74$ para Total Positivo.

\section{Procedimiento}

\section{Traducción de ítems}

Se ha llevado a cabo un proceso de traducción inversa de los ítems del BASC-S2 siguiendo la recomendación de Hambleton y Patsula (1999) en la adaptación de un instrumento de medida de una cultura a otra. Cada elemento de la versión española se ha traducido al euskara por dos traductores profesionales independientes. Tras compararse y discutirse las dos traducciones, se han reducido a una formulación única. A partir de esta versión, dos traductores de perfiles similares a 
los de la fase anterior, han traducido la versión en euskara al español. Después de comparar las dos versiones se ha logrado una versión única del BASC en español. Por último, se ha comparado cada ítem de la versión original en español con la versión adaptada inversamente, y examinado la posible falta de equivalencia de significado. En base a este análisis, se han realizado algunos cambios en la versión vasca del BASC.

\section{Presentación del proyecto en los centros educativos y aplicación de las pruebas}

Se ha presentado el estudio a las direcciones de los centros, las cuales, a su vez, lo han presentado en los claustros de profesorado. Con los centros educativos que han aceptado participar se ha pactado el envío de un protocolo de consentimiento informado a las familias. El alumnado participante ha entregado el consentimiento informado a sus profesores tutores y se ha procedido a la aplicación de las pruebas. A los participantes se les ha informado sobre la confidencialidad y anonimato de los resultados. Se han administrado los dos cuestionarios de forma colectiva en cada clase y en una única sesión en horario regular lectivo, necesitando aproximadamente una hora para cumplimentarlos. Las instrucciones relativas a los dos cuestionarios administrados han sido leídas en voz alta. La aplicación ha sido realizada a lo largo de un año (2010-2011) por psicólogas y becarias formadas con esta finalidad. Para analizar los datos se ha utilizado el paquete estadístico PASW18 y la versión 6.1 del programa EQS. Se han eliminado de los análisis todos los casos que no cumplen con los criterios de validez de acuerdo con los índices $\mathrm{F}$ y $\mathrm{V}$ de validez del BASC.

\section{Análisis de datos}

En primer lugar, se han calculado los porcentajes referidos a las tasas de desajuste y síntomas emocionales, y, posteriormente, se han realizado tres análisis ANOVA modelo $2 \times 3$ con el sexo del participante (chico $v s$. chica) $\mathrm{x}$ edad (8-9 años; 10-11 años; y 12 años), siendo las variables dependientes desajuste escolar, desajuste clínico y síntomas emocionales. Además, se ha obtenido un modelo de regresión para la predicción del desajuste escolar, basado tanto en las escalas clínicas como las escalas adaptativas del BASC.

En segundo lugar, para analizar la estructura factorial de la escala se ha aplicado un análisis de componentes principales con la rotación Oblimin. Posteriormente, se han calculado los índices de asimetría y curtosis de las 12 escalas. Se asume que los valores alrededor de 1 se alejan ligeramente de la distribución normal, los valores entre 1 y 2.3 se consideran con una moderada falta de normalidad, y los valores por encima de 2.3 tienen una marcada 
anormalidad (Lei y Lomax, 2005). En el análisis factorial confirmatorio, para el examen de la bondad de ajuste de los modelos se han utilizado el estadístico Chi-cuadrado dividido por los grados de libertad $\left(\chi^{2} / \mathrm{g} 1.\right)$, el Índice Comparativo de Ajuste (CFI), Índice de ajuste de incremento de Bollen (IFI), el Índice de ajuste no-normativo de BentlerBonett (NNFI) y Error cuadrático medio de aproximación (RMSEA). Valores de $\chi^{2} / \mathrm{gl}$. inferiores a 5 representan un buen ajuste del modelo (Bollen, 1989); en general se aceptan valores iguales o inferiores a .08 en el índice RMSEA aunque algunos autores prefieren poner el punto de corte en .06 (Hu y Bentler, 1999) y por último valores por encima de .90 en los índices CFI, IFI y NNFI se consideran aceptables (Bentler, 2006).

En tercer lugar, se han generado los coeficientes Alfa de Cronbach de cada factor para evaluar la consistencia interna (Cronbach, 1951) y se ha adoptado el criterio de Nunnally (1978) alfa $\geq .70$ para considerar la fiabilidad aceptable en el ámbito de la Psicología. Partiendo de que, en comparación con las dimensiones Desajuste escolar o Desajuste clínico, los ítems correspondientes a la dimensión Ajuste personal evalúan de forma inversa el constructo al que se refieren, éstos han sido recodificados previamente. Por ejemplo, para calcular el coeficiente alfa de Ajuste personal se ha recodificado los ítems referidos a Depresión porque es una escala negativa mientras el resto son positivas.

\section{Resultados}

\section{Desajuste escolar, desajuste clínico y síntomas emocionales}

Según las puntuaciones obtenidas en el BASC S-2, el 4.7\% de los estudiantes de la muestra presenta desajuste escolar, el $4.2 \%$ desajuste clínico y el 4.4\% síntomas emocionales clínicamente significativos. Además, el $10.8 \%$ de los estudiantes están en riesgo de tener desajuste escolar, el $15.2 \%$ de presentar desajuste clínico, y el $8.7 \%$ de tener síntomas emocionales. Con el objetivo de verificar si el nivel de desajuste escolar, desajuste clínico y síntomas emocionales variaban en función del sexo y de la edad de los participantes, se han realizado tres análisis ANOVA modelo 2 (sexo) $\times 3$ (edad) de medidas independientes. En el ANOVA para el desajuste escolar solamente el sexo ha resultado significativo $[F(1,778)=8.98, p=.003]$, siendo el nivel de desajuste escolar mayor en niños $(M=54.4)$ que en niñas $(M=50.3)$. En el ANOVA para el desajuste clínico la interacción es casi significativa $[F(2,778)=2.80$, $p=.06)]$. Los resultados del tercer análisis han mostrado un efecto principal significativo del sexo $[F(1,779)=8.47, p=.004], \mathrm{y}$ una interacción significativa entre el sexo y la edad $[F(2,779)=4.33$, 


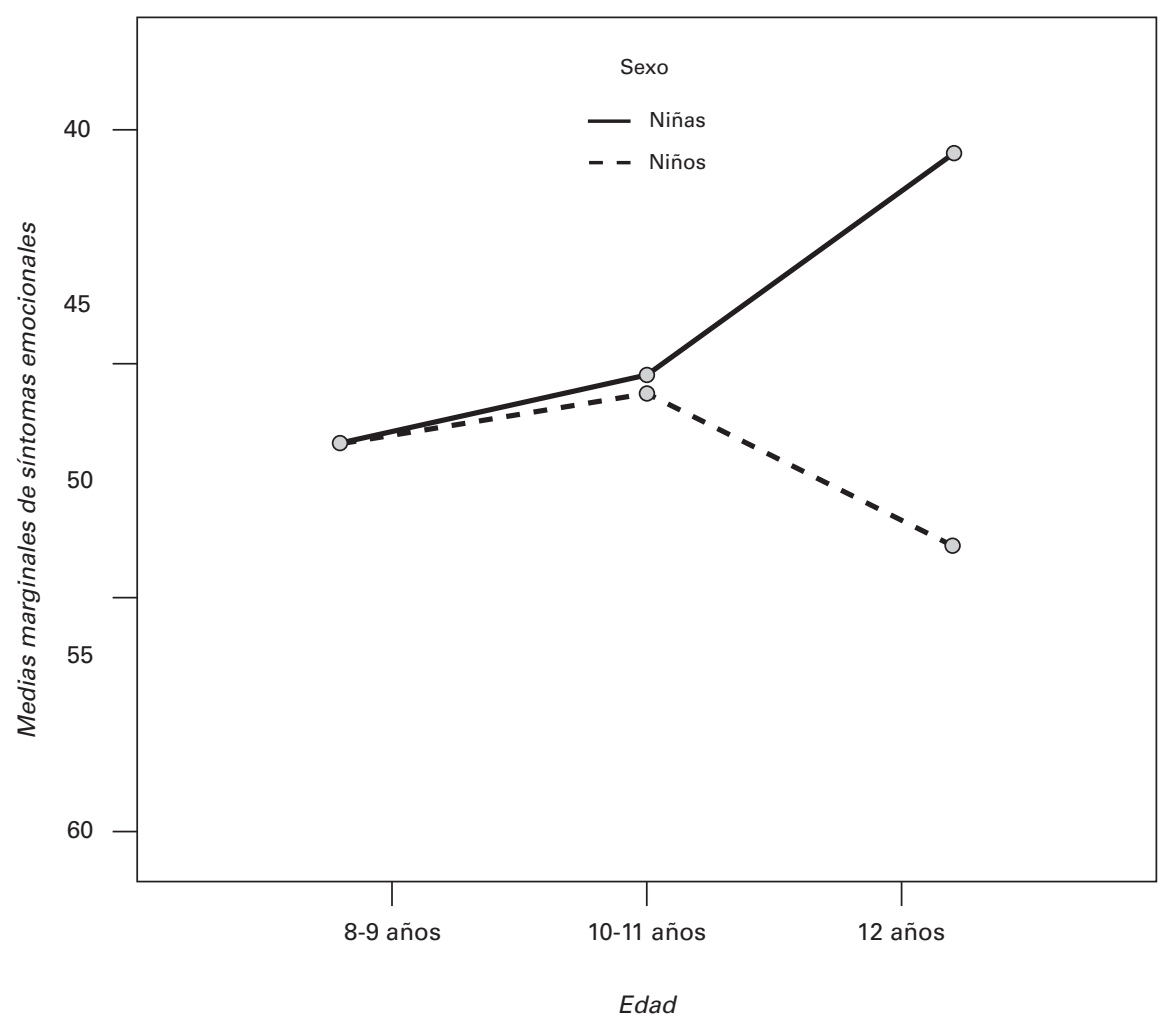

Figura 1. Nivel de síntomas emocionales en función del sexo y la edad.

$p=.01$ )] (ver figura 1). El análisis de la interacción se ha realizado a través de las pruebas post-hoc de Tukey y se ha verificado que en el grupo de 12 años las chicas presentan significativamente más síntomas emocionales que los chicos $(p=.03)$, mientras que en los otros dos grupos no hay diferencias.

El desajuste escolar correlaciona significativamente con síntomas emocionales $(r=.32)$, desajuste clínico $(r=.26)$, depresión (CDS) $(r=.24)$ y tristeza $(r=.26)$. Se ha realizado un análisis de regresión incluyendo en el mismo todas las escalas del BASC, con el fin de analizar cuáles de ellas eran variables predictoras del desajuste escolar. Dos variables correspondientes a las escalas clínicas (sentido de incapacidad y locus de control) y otras dos variables de las escalas adaptativas (relaciones con los padres y 
Tabla 1

Predictores del Desajuste Escolar

\begin{tabular}{lrrrrc}
\hline & \multicolumn{5}{c}{ Desajuste escolar } \\
\cline { 2 - 6 } & \multicolumn{1}{c}{$B$} & Error típ. $B$ & \multicolumn{1}{c}{$\beta$} & \multicolumn{1}{c}{$T$} & \multicolumn{1}{c}{$p$} \\
\hline Constante & 45.81 & 2.90 & & 15.79 & .001 \\
Sentido de incapacidad & .18 & .04 & .18 & 4.78 & .001 \\
Locus de control & .19 & .04 & .20 & 5.23 & .001 \\
Relaciones con los padres & -.15 & .03 & -.17 & -5.00 & .001 \\
Confianza en sí mismo & -.11 & .03 & -.12 & -3.60 & .001 \\
\hline
\end{tabular}

Nota: $R^{2}=.21, p<.001$.

confianza en sí mismo) han resultado factores predictores válidos del desajuste escolar, llegando a explicar el modelo el $21 \%$ de la varianza (ver tabla 1).

\section{Validación del BASC-S2}

\section{Estructura factorial}

El índice Kaiser-Meyer-Olkin (KMO) ha sido de .89, lo que podría considerarse un valor adecuado (Field, 2005), indicando que el tamaño de la muestra es aceptable para la cantidad de variables a analizar. La prueba de esfericidad de Barlett es estadísticamente significativa $\chi^{2}(66)=4621.74, p<.001$, lo cual significa que el análisis factorial resulta pertinente.

Con el fin de examinar la dimensionalidad de la escala, se llevó a cabo un análisis de componentes principales con la rotación Oblimin. Según el criterio estándar de Kaiser-Guttman (autovalores iniciales mayores a 1 ), se definieron
3 factores que explicaban el $60.5 \%$ de la varianza total. El primer factor $($ autovalor $=4.7)$ explica el $39 \%$ de la varianza total y corresponde a la dimensión Desajuste clínico, el segundo factor (autovalor $=1.50$ ) representa un $12.5 \%$ reflejando la dimensión Ajuste personal mientras que el tercer factor (autovalor $=1.08)$ representa un $9 \%$ y se refiere al Desajuste escolar (ver la tabla 2). Se han considerado interpretables aquellas cargas factoriales de .40 y superiores.

\section{Análisis factorial confirmatorio}

El análisis factorial confirmatorio (AFC) de partida ha sido el modelo teórico inicial (Reynolds y Kamphaus, 1992). Del total de participantes, el 99.9\% $(n=787)$ tiene los datos completos en este análisis, y se ha utilizado el método de máxima verosimilitud para el tratamiento de los valores perdidos (p.e., Arbuckle, 1996; Jamshidian y Bentler, 1998). Se ha llevado a cabo un 
Tabla 2

Matriz de Configuración tras la

Realización del Análisis de Componentes

Principales y rotación Oblimin

\begin{tabular}{llll}
\hline & \multicolumn{3}{c}{ Factor } \\
\cline { 2 - 4 } & 1 & 2 & 3 \\
\hline Actitud negativa hacia el & & & \\
$\quad$ colegio & & & .80 \\
Actitud negativa hacia los & & & \\
$\quad$ profesores & & & .62 \\
Atipicidad & .82 & & \\
Locus de control & .71 & & \\
Estrés social & .71 & & \\
Ansiedad & .84 & & \\
Depresión & .64 & & \\
Sentido de incapacidad & .66 & & \\
Relaciones interpersonales & & .62 & \\
Relaciones con los padres & & .71 & \\
Autoestima & & .58 & \\
Confianza en sí mismo & & .63 & \\
\hline
\end{tabular}

Nota: Se han eliminado las correlaciones inferiores a l.40I para facilitar la interpretación.

análisis factorial confirmatorio con 12 variables observadas y 3 factores latentes, contribuyendo cada escala a una sola dimensión. Las variables latentes que se han incluido en el modelo han sido: Ajuste Personal (indicadores: Relaciones interpersonales, Relaciones con los padres, Autoestima y Confianza en sí mismo), Desajuste Escolar (indicadores: Actitud negativa hacia el colegio y Actitud negativa hacia los profesores) y Desajuste Clínico (Sentido de incapacidad, Locus de control, Atipicidad, Ansiedad, Estrés Social y Depresión). Los índices de ajuste están basados en el método robusto, porque la distribución multivariada no es normal (coeficiente estandarizado de Yuan, Lambert y Fouladi $=41.48$ ). La ausencia de normalidad es debida principalmente a dos variables: Relaciones personales (asimetría $=-2.62$ y curtosis $=7.95)$ y Autoestima (asimetría $=-2.25$ y curtosis $=5.26)$. Con el método de Yuan-Bentler (2000) el valor de $\chi^{2}$ se reducía en 98 puntos, pero los índices de bondad de ajuste del modelo inicial seguían sin ser aceptables, $Y-B \chi^{2}(51, N=791)=357.6$; $R C F I=.86 ; R N N F I=.82$; $R I F I=.86 ; R M S E A=.087$; $C I=.079, .096 ; Y-B \quad \chi^{2}(51$, $N=791)=456.2 ; R C F I=.88 ; R N-$ $N F I=.84 ; R I F I=.88 ; R M S E A=.10$; $C I=.092, .11$.

El modelo del estudio original y el de la adaptación española son muy similares (ver Anexos 1 y 2), pero tres indicadores contribuyen a dos variables latentes: la depresión (desajuste clínico y ajuste personal), el locus de control (desajuste escolar y clínico) y el sentido de incapacidad (desajuste escolar y clínico). Además, en la adaptación española la escala Estrés Social es un indicador del factor latente Ajuste personal, mientras que en el modelo del estudio original se incluye una correlación entre las escalas de Estrés social y Relaciones interpersonales. Por otra parte, en la adaptación española las Relaciones con los padres es una variable observable correspondiente a las variables latentes Ajuste personal y Desajuste escolar. En el presente estudio el modelo 


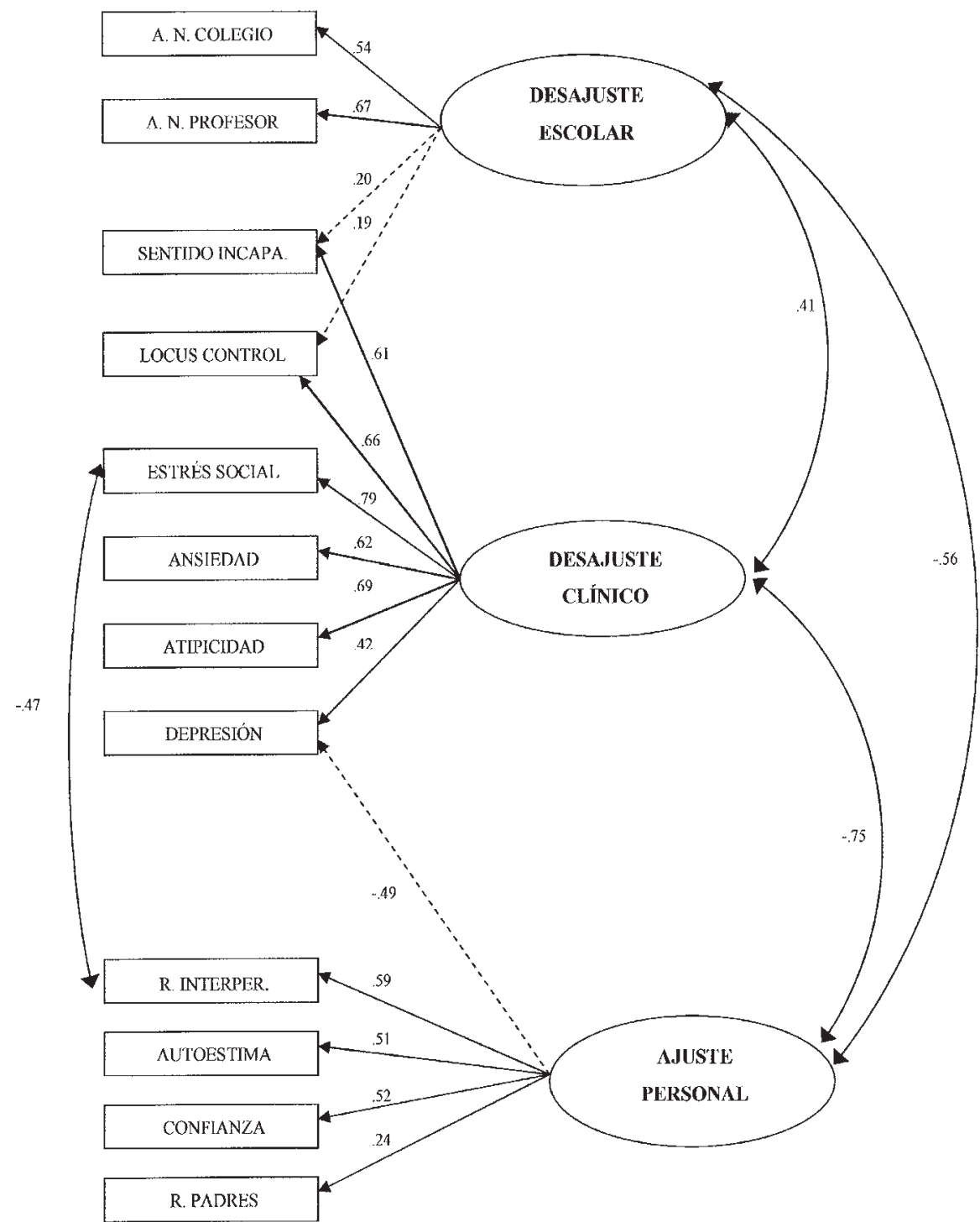

Nota: A. N. Colegio: Actitud negativa hacia el colegio; A. N. Profesor: Actitud negativa hacia el profesor o la profesora; Sentido Incapa.: Sentido de incapacidad; R. Interper.: Relaciones interpersonales; Confianza: Confianza en sí mismo; R. Padres: Relaciones con los padres.

Figura 2. Modelo de medida final de la adaptación vasca del BASC, autoinforme S-2. 
de la adaptación española presenta un ajuste bastante aceptable según los criterios de Bentler (2006): $Y-B \chi^{2}(46, N=791)=218.5$; RCFI $=.92 ; R N N F I=.89$; $R I F I=.92 ; R M S E A=.069 ; C I=.06$, $.078 ; \chi^{2}(46, N=791)=276.9$; $C F I=.93 ; N N F I=.90 ; I F I=.93$; RMSEA $=.08 ; C I=.07, .09$. No obstante, el modelo del estudio original se ajusta algo mejor a los datos de la adaptación vasca, $Y$ - $B \chi^{2}(47$, $N=791)=212.5$; RCFI = .92; RNNFI $=.89 ;$ RIFI $=.92$; RMSEA $=.067 ; C I=.058$, $.076 ; \chi^{2}(47, N=791)=262.4$; $C F I=.93 ; N N F I=.93 ; I F I=.93$; RMSEA $=.076 ; C I=.067, .085$ (véase la figura 2). El cociente $\chi^{2} /$ $g l$ alcanza un valor de 4.5. Aunque algunas variables observables tienen saturaciones relativamente bajas $(<.30)$, éstas son significativas y se ha decidido mantenerlas en el modelo para facilitar las comparaciones transculturales.

El modelo final de la figura 2 preserva la estructura de tres factores de la versión original en inglés, lo que es sustancialmente relevante a nivel teórico, porque habiéndose sometido a prueba las características psicométricas del BASC, los resultados del presente estudio corroboran la fortaleza del modelo original. Por un lado, en el análisis factorial exploratorio se ha obtenido un modelo de tres factores con cargas factoriales relativamente elevadas y sin cargas cruzadas en más de un factor. Por otro lado, con el análisis factorial confirmatorio se verifica la adecuación del modelo, ya que las cargas factoriales han sido significativas y aceptables, del mismo modo que los índices de bondad de ajuste han sido admisibles. Como excepción, cabe señalar que la escala Relaciones con los padres presentaba una carga factorial inferior a .30 asignado al factor Ajuste personal.

\section{Consistencia interna}

En relación a las dimensiones globales, los análisis de fiabilidad presentan una buena consistencia interna del desajuste clínico $(\alpha=.92)$, ajuste personal $(\alpha=.80)$, desajuste escolar $(\alpha=.79)$ y síntomas emocionales $(\alpha=.84)$, ya que superan el criterio de Nunnally (1978) de $\alpha \geq .70$ para considerar la fiabilidad adecuada.

En la tabla 3 se presentan los coeficientes alfa obtenidos en este estudio y los obtenidos en el estudio de la adaptación española. Se ha hallado una mayor variabilidad en la fiabilidad de las escalas que en las dimensiones globales. Por término medio la consistencia interna de las escalas está alrededor de .69, variando desde .32 (Relaciones con los padres) a .83 (Ansiedad). Es reseñable el bajo índice de fiabilidad obtenido en la escala Relaciones con los padres. En el estudio de la adaptación española del S-2 esta escala es la que presenta el coeficiente alfa más bajo $(\alpha=.56)$ aunque en la adaptación vasca el índice de fiabilidad ha sido tan bajo que resulta desaconsejable la utilización de esta 
Tabla 3

Comparación de la Consistencia Interna de la Adaptación Española y de la Vasca del BASC S-2

\begin{tabular}{lcc}
\hline \multirow{2}{*}{ Escala } & \multicolumn{2}{c}{$\alpha$ de Cronbach } \\
\cline { 2 - 3 } & $\begin{array}{c}\text { Este estudio } \\
(n=795)\end{array}$ & $\begin{array}{c}\text { Adaptación española } \\
(n=528)\end{array}$ \\
\hline Actitud negativa hacia el colegio & .73 & .81 \\
Actitud negativa hacia los profesores & .50 & .71 \\
Ansiedad & .83 & .81 \\
Atipicidad & .77 & .79 \\
Locus de control & .71 & .77 \\
Estrés social & .71 & .72 \\
Depresión & .72 & .83 \\
Sentido de incapacidad & .62 & .72 \\
Relaciones interpersonales & .64 & .83 \\
Relaciones con padres & .32 & .56 \\
Autoestima & .67 & .75 \\
Confianza en sí mismo & .55 & .61 \\
\hline Mediana & .69 & .76 \\
\hline
\end{tabular}

escala de forma específica. El índice de discriminación de todos los ítems de esta escala es aceptable $(I D>.30)$, y el coeficiente alfa no mejora si se elimina algún ítem de la escala.

\section{Evidencias de validez de concurrente}

Para evaluar la validez concurrente de la versión vasca del BASC se ha decidido incluir la Escala de depresión para niños (CDS, Lang y Tisher, 1983), ya que es de amplio uso por parte de los profesionales, y cuenta con algunos estudios de adaptación a la lengua vasca (p.e., Balluerka, Gorostiaga, y Haranburu, en revisión). Aunque la mayoría de las escalas del CDS no tienen una escala paralela clara en el S2, el análisis de correlaciones ofrece interesantes resultados. En primer lugar, se han correlacionado las dimensiones generales del BASC versus las del CDS, junto a tres escalas específicas: depresión, autoestima y problemas sociales (ver la tabla 4). Cabe indicar que la puntuación de la escala Total Positivo es de tipo inverso, es decir, a mayor puntuación en la escala, mayor carencia de dichos sentimientos. En el manual se hace referencia a este factor como tristeza. En cuanto a la autoestima, el CDS mide los sentimientos, conceptos y actitudes negativas del niño 
Tabla 4

Correlaciones entre las escalas del BASC S-2 y las escalas del CDS

\begin{tabular}{lcccccc}
\hline \multirow{2}{*}{ CDS } & \multicolumn{6}{c}{ BASC } \\
\cline { 2 - 7 } & $\begin{array}{l}\text { Desajuste } \\
\text { clínico }\end{array}$ & $\begin{array}{c}\text { Ajuste } \\
\text { personal }\end{array}$ & $\begin{array}{c}\text { Síntomas } \\
\text { emocionales }\end{array}$ & Depresión & Autoestima & $\begin{array}{c}\text { Relaciones } \\
\text { interpers. }\end{array}$ \\
\hline Tristeza & $.16^{* *}$ & $-.45^{* *}$ & $.28^{* *}$ & $.30^{* *}$ & $-.27^{* *}$ & $-.21^{* *}$ \\
Depresión & $.66^{* *}$ & $-.39^{* *}$ & $.67^{* *}$ & $.57^{* *}$ & $-.30^{* *}$ & $-.37^{* *}$ \\
Autoestima & $.57^{* *}$ & $-.39^{* *}$ & $.60^{* *}$ & $.50^{* *}$ & $-.33^{* *}$ & $-.33^{* *}$ \\
Problemas sociales & $.16^{* *}$ & $-.41^{* *}$ & $.28^{* *}$ & $.30^{* *}$ & $-.27^{* *}$ & $-.44^{* *}$ \\
\hline
\end{tabular}

** $p<.001$.

en relación con su propia estima y valor, mientras que en el BASC indica una autoestima positiva.

En general, la autoestima del CDS está asociada moderadamente con todas las escalas del BASC analizadas en este apartado. Los resultados obtenidos indican que las escalas depresión $(r=.57, p<.001)$, autoestima $(r=-.33, p<.001) \mathrm{y}$ problemas sociales/relaciones interpersonales $(r=-.44, p<.001) \mathrm{de}$ los cuestionarios BASC y CDS correlacionan de forma razonable. En cuanto al resto de correlaciones, las relaciones encontradas van en la dirección esperada y en aquellas variables y constructos entre los que cabía esperar un vínculo teórico. La escala de problemas sociales del CDS presenta una asociación inversa y significativa con el ajuste personal del BASC $(r=-.41)$. Finalmente, se ha confirmado la importancia de las variables tristeza (Total positivo) $(\beta=.21, p<.001) \mathrm{y}$ depresión (Total depresivo) $(\beta=.53$, $p<.001)$ como variables predicto- ras de la depresión, $R^{2}=.36, F(2$, 602) $=188.26, p<.001$.

\section{Discusión}

El primer objetivo de este estudio ha sido examinar la tasa de desajuste escolar, desajuste clínico y síntomas emocionales de una muestra de escolares de la Comunidad Autónoma del País Vasco y analizar si existen diferencias en función del sexo y la edad. Dado que la muestra procede del contexto escolar, resulta de especial interés analizar sus niveles de desajuste escolar: un 4.7\% presenta una puntuación clínicamente significativa mientras que un $10.8 \%$ está en riesgo. Estos datos indican que en torno a un $15 \%$ del alumnado, expresa cierta aversión hacia el ámbito escolar (actitud negativa hacia el profesorado y hacia el colegio), datos que no se pueden desligar de la asociación positiva hallada entre el desajuste escolar y el desajuste clínico o los síntomas 
emocionales: los niveles altos de desajuste escolar están relacionados con niveles elevados de desajuste clínico y síntomas emocionales como la depresión y la tristeza. En relación al desajuste clínico, los resultados han mostrado que cerca de un $20 \%$ de la muestra estudiada presenta síntomas de desajuste clínico (4.2\% sintomatología severa y el $15.2 \%$ está en riesgo). Así, los porcentajes cercanos al $20 \%$ se corresponden con estudios previos sobre la temática (López-Soler et al., 2009; Romero et al., 2010), que indican que se trata de un colectivo que requiere una atención especial, para evitar que esos síntomas se cronifiquen. Además, el 13\% de los escolares presenta síntomas emocionales (4.4\% síntomatología severa y $8.7 \%$ en riesgo).

En el presente estudio los niños varones muestran mayor desajuste escolar que las niñas, en la línea de lo hallado por Essau et al. (2000). Así, parece que los niños varones expresan su desazón emocional de forma más explícita en el colegio, siendo más evidente su desajuste escolar. La literatura científica así lo confirma, ya que señala que los profesores suelen informar sobre mayor desajuste escolar en los chicos que en las chicas (Baker, 2006; Cava, Buelga, Musitu, y Murgui, 2010). Además, en este estudio, se ha encontrado una interacción significativa entre el sexo y la edad para los síntomas emocionales que podría explicar los resultados contradictorios encontrados en investigaciones previas. Es decir, estos resultados indican que a la hora de estudiar los síntomas emocionales en la infancia, es importante tener en cuenta tanto el sexo como la edad de los escolares. En concreto se encontró que a los 12 años las niñas presentaban más sintomatología emocional que los niños, y este resultado ha sido confirmado parcialmente por algunos estudios que indican una mayor tendencia de las niñas a presentar sintomatología emocional, de tipo ansioso (Crijnen et al., 1999; Romero et al., 2010), o depresivo a medida que se van acercando a la adolescencia (Angold et al., 2002).

Los resultados del presente estudio confirman que el sentido de incapacidad y el locus de control externo son factores de riesgo de desajuste escolar, mientras que la buena relación con los padres y la confianza en sí mismo son factores protectores. Las personas con un locus de control externo utilizan más estrategias centradas en la emoción y menos estrategias centradas en el problema que aquellas personas con un locus de control interno (Terry, 1994), porque creen que sus esfuerzos no serán efectivos para influir en el resultado de una situación concreta (Lazarus y Folkman, 1984). Por lo tanto, la labor de padres y profesores sería hacer sentir a los estudiantes que son competentes y parte activa de su aprendizaje para favorecer un mayor ajuste personal, social y escolar.

Este estudio plantea un segundo objetivo: la adaptación al euskara 
del cuestionario BASC (S2). Los análisis factoriales confirmatorios han permitido establecer la validez de la escala en esta población, además de contrastar el modelo defendido por los autores del instrumento, que había mostrado un ajuste adecuado. Los resultados indican que la versión vasca tiene una estructura de tres factores al igual que la versión original del instrumento, y la versión española: el desajuste escolar (actitud negativa hacia el colegio, la actitud negativa hacia el profesor, sentido de incapacidad y locus de control), desajuste clínico (sentido de incapacidad, locus de control, estrés social, ansiedad, depresión y atipicidad) y el ajuste personal (depresión, relaciones interpersonales, autoestima, confianza en sí mismo y relaciones con los padres). Algunas variables tienen cargas factoriales en dos factores latentes al igual que en el estudio original. Por ejemplo, locus de control y el sentimiento de incapacidad pertenecen tanto al desajuste escolar como al desajuste clínico. Por otra parte, la depresión se incluye al mismo tiempo en la dimensión de desajuste clínico y ajuste personal.

En relación a la fiabilidad del instrumento, las dimensiones generales del BASC (desajuste escolar, desajuste clínico, ajuste personal y síntomas emocionales) presentan una adecuada consistencia interna. En cuanto a la fiabilidad de las escalas, ésta ha sido aceptable en general, aunque con alguna excepción, como la escala Relaciones con los padres que, al igual que en la versión española, ha obtenido el índice de fiabilidad inferior. Futuras investigaciones deberían examinar detalladamente esta escala y los ítems que la componen, para llegar a una mejor definición del mismo, omitiendo algunos ítems o sustituyéndolos por otros culturalmente más apropiados. Por otro lado, se han encontrado pruebas que apoyan la existencia de validez concurrente del BASC. Como cabría esperar, las dimensiones depresión, autoestima y relaciones interpersonales del BASC muestran una relación moderada y significativa con las dimensiones correspondientes del CDS.

En definitiva, el BASC en su versión vasca del autoinforme para escolares entre 8 y 12 años presenta características psicométricas semejantes a las de la versión española, ofreciendo garantías suficientes para ser utilizado como instrumento de evaluación de los trastornos de la infancia en la población vascoparlante. Se cuenta así con un instrumento que permite evaluar los problemas emocionales, de relaciones sociales y de conducta de forma conjunta o por separado, atendiendo a una serie de indicadores que han mostrado su validez en la versión vasca. Los resultados obtenidos de esta prueba pueden facilitar la identificación de factores de riesgo, así como el diseño, planificación, implementación y evaluación de medidas de atención temprana.

La limitación principal de este estudio es la selección de los par- 
ticipantes, ya que proviene de una muestra de conveniencia perteneciente al País Vasco. En futuras investigaciones se podrían replicar los resultados encontrados en este estudio utilizando muestras procedentes de contextos clínicos. Asimismo sería interesante analizar la estabilidad temporal del BASCS2 (fiabilidad test-retest) y adaptar a la población vascoparlante el resto de los niveles de instrumento (3-6 años y 12-18 años) tanto en el formato de autoinforme como los cuestionarios para padres y para tutores.

\section{Referencias}

Aláez, M., Martínez-Arias, R., y Rodríguez-Sutil, C. (2000). Prevalencia de trastornos psicológicos en niños y adolescentes, su relación con la edad y el género. Psicothema, 12, 525-532.

American Educational Research Association (AERA), American Psychological Association (APA) y National Council on Measurement in Education (NCME) (1999). Standards for Educational and Psychological Testing. Washington DC: American Psychological Association.

American Psychiatric Association, APA. (2002). Manual Diagnóstico y Estadístico de los Trastornos Mentales (cuarta edición, texto revisado). Barcelona: Masson.

Angold, A., Costello, E., y Worthman, C. (1998). Puberty and depression: The roles of age, pubertal status and pubertal timing. Psychological Medicine, 28, 51-61.

Angold, A., Erkanli, A., Farmer, E. M. Z., Fairbank, J. A., Burns, B. J., Keeler, G., y Costello, E. J. (2002). Psychiatric disorder, impairment, and service use in rural African
American and White youth. Archives of General Psychiatry, 59, 893-901. doi: 10.1001/archpsyc.59.10.893.

Angold, A., Erkanli, A., Silberg, J., Eaves, L., y Costello, E. J. (2002). Depression scale scores in 8-17-year-olds: Effects of age and gender. Journal of Child Psychology and Psychiatry, 43, 10521063. doi: 10.1111/1469-7610.00232.

Arbuckle, J. L. (1996). Full information estimation in the presence of incomplete data. En G. A. Marcoulides y R. E. Schumacker (Eds.), Advanced structural equation modeling: Issues and Techniques (pp. 243-277). Mahwah, NJ: Lawrence Erlbaum Associates.

Axelson, D. A., y Birmaher, B. (2001). Relation between anxiety and depressive disorders in childhood and adolescence. Depression and Anxiety, 14, 67-78. doi: 10.1002/da.1048.

Balluerka, N., Gorostiaga, A., y Haranburu, M. (en revisión). Validación del CDS (Escala de Depresión Infantil) en población vascoparlante. The Spanish Journal of Psychology.

Baker, J. A. (2006). Contributions of teacher-child relationships to positive 
school adjustment during elementary school. Journal of School Psychology, 44, 211-229. doi: 10.1016/ j.jsp.2006.02.002.

Bentler, P. M. (2006). EQS, Structural Equations Program Manual. Encino, CA: Multivariate Statistical Software, Inc.

Bollen, K. A. (1989). Structural equations with latent variables. Wiley Series in Probability and Mathematical Statistics. New York: Wiley.

Bragado, C., Carrasco, I., Sánchez, M. L., y Bersabé, R. M. (1996). Trastornos de ansiedad en escolares de 6 a 17 años. Ansiedad y Estrés, 2, 97-112.

Cancio, E. J., West, R. P., y Young, K. R. (2004). Improving mathematics homework completion and accuracy of students with EBD through selfmanagement and parent participation. Journal of Emotional and Behavioral Disorders, 12, 9-22. doi: $10.1177 / 10634266040120010201$.

Carney, A. G., y Merrell, K. W. (2002). Reliability and comparability of a Spanish-language form of the preschool and kindergarten behaviour scales. Psychology in the Schools, 39, 367-373. doi: 10.1002/pits.10033.

Cava, M. J., Buelga, S., Musitu, G., y Murgui, S. (2010). Violencia escolar entre adolescentes y sus implicaciones en el ajuste psicosocial: un estudio longitudinal. Revista de Psicodidáctica, 15, 21-34.

Cole, D. A. (1991). Preliminary support for a competency-based model of depression in children. Journal of $A b$ normal Psychology, 100, 181-190. doi: 10.1037/0021-843X.100.2.181.

Crijnen, A., Achenbach, T., y Verhulst, F. (1999). Problems reported by parents Syndrome Constructs. American Journal of Psychiatry, 156, 569574.
Cronbach, L. J. (1951). Coefficient alpha and the internal structure of the test. Psychometrika, 16, 297-334.

Del Barrio, V. (1995). Evaluación clínica infantil y adolescente. En F. Silva (ed.), Evaluación psicológica en niños y adolescentes (pp. 461-530). Madrid: Síntesis Psicológica.

Del Barrio, V. (2000). La depresión infantil. Factores de riesgo y posibles soluciones. Málaga: Aljibe.

Del Barrio, V. (2010). La depresión infantil a la altura de nuestro tiempo. Información Psicológica, 100, 49-59.

Denham, S. A. (2006). Social-emotional competence as support for school readiness: What it is and how do we assess it? Early Education and Development, 17, 57-89. doi: 10.1207/ s15566935eed1701_4.

Escobar, M., Trianes, M. V., FernándezBaena, F. J., y Miranda, J. (2010). Relaciones entre Aceptación Sociométrica Escolar e Inadaptación Socioemocional, Estrés Cotidiano y Afrontamiento. Revista Latinoamericana de Psicología, 42, 469-479.

Escobar, M., Fernández-Baena, F. J., Miranda, J., Trianes, M. V., y Cowie, H. (2011). Baja aceptación de los iguales e inadaptación emocional/conductual en escolares: Efectos del estrés cotidiano, afrontamiento y sexo. Anales de Psicología, 27, 412-417.

Essau, C. A., Conradt, J., y Petermann, F. (2000). Frequency, comorbidity, and psychosocial impairment of depressive disorders in adolescents. Journal of Adolescent Research, 15, 470-481. doi: 10.1177/0743558400154003.

EUSTAT, Instituto de Estadística de Euskadi (2011). http://www.eustat.es/bancopx/spanish/Sociedad/ Educación/Enseñanza/Actividad\%20 educativa/Actividad\%20educativa. html\#axzz1T16v32kD 
Ferguson, D. M., y Woodward, L. J. (2002). Mental health, educational and social role outcomes of adolescents with depression. Archives of General Psychiatry, 59, 225-231. doi: 10.1001/archpsyc.59.3.225.

Field, A. (2005). Discovering statistics using SPSS (2. ${ }^{\mathrm{a}}$ ed.). Thousand Oaks, CA: Sage.

Fleming, J. E., y Offord, D. R. (1990). Epidemiology of childhood depressive disorders: A critical review. Journal of the American Academy of Child and Adolescent Psychiatry, 29, 571-580. doi: 10.1097/00004583199007000-00010.

González, J., Fernández, S., Pérez, E., y Santamaría, P. (2004). Adaptación española del sistema de evaluación de la conducta en niños y adolescentes: BASC. Madrid: TEA.

Hambleton, R. K., y Patsula, L. (1999). Increasing the validity of adapted tests: Myths to be avoided and guidelines for improving test adaptation practices. Journal of Applied Testing Technology, 1, 1-30.

Harden, B. J., Winslow, M. B., Kendziora, K. T., Shahinfar, A., Rubin, K. H., Fox, N. A., et al. (2000). Externalizing problems in Head Start children: An ecological exploration. Early Education \& Development. Special Issue: Mental Health and Head Start, 11, 357-385.

Herman, K. C., Lambert, S., Reinke, W. M., y Ialongo, N. (2008). Low academic competence in first grade as a risk factor for depressive cognitions and symptoms in middle school. Journal of Counselling Psychology, 55, 400-410. doi: 10.1037/ a0012654.

Holmbeck, G. N., Welborn, A., Bachanas, P., Garber, J., Bearman, K., Abad, M., et al. (2008). Evidence-based assess- ment in pediatric psychology: measures of psychological adjustment and psychopathology. Journal of Pediatric Psychology, 33, 958-980. doi: 10.1093/jpepsy/jsm059.

Hu, L., y Bentler, P. M. (1999). Cutoff criteria for fit indexes in covariance structure analysis: Conventional criteria versus new alternatives. Structural Equation Modeling, 6, 1-55. doi: 10.1080/10705519909540118.

Jamshidian, M., y Bentler, P. M. (1998). A quasi-Newton method for minimum trace factor analysis. Journal of Statistical Computation and Simulation, 62, 73-89. doi: 10.1080/00949659808811925.

Keane, S. P., y Calkins, S. D., (2004) Predicting kindergarten peer social status from toddler and preschool problem behavior. Journal of Abnormal Child Psychology, 32, 409423. doi: 10.1023/B:JACP.0000030 294.11443.41.

Kovacs, M., Feinberg, T. L., CrouseNovak, M. A., Paulauskas, S. L., y Finkelstein, R. (1984). Depressive disorders in childhood. I. A longitudinal prospective study of characteristics and recovery. Archives of General Psychiatry, 41, 229-237. doi: 10.1001/ archpsyc.1984.01790140019002.

Kovacs, M. (2010). Prodromal symptoms and atypical affectivity as predictors of major depression in juveniles: Implications for prevention. Journal of Child Psychology and Psychiatry, 51, 472-496. doi: 10.1111/j.14697610.2010.02230.x.

Lacalle, M. (2009). Escalas DSM del CBCL y YSR en niños y adolescentes que acuden a consulta en servicios de salud mental. (Tesis doctoral. Facultad de Psicología. Universidad Autónoma de Barcelona). 
Lang M., y Tisher M. (1983). Children's Depression Scale, second research edition. Camberbell, Victoria, Australia: Australian Council for Educational Research.

Lazarus, R., y Folkman, S. (1986). Estrés y procesos cognitivos. Barcelona: Martínez Roca.

Lei, M., y Lomax, R. G. (2005). The effect of varying degrees of nonnormality in structural equation modeling. Structural Equation Modeling: A Multidisciplinary Journal, 12, 1-27. doi: 10.1207/s15328007sem1201_1.

López-Soler, C., Castro, M., Alcántara, M., Fernández, V., y López Pina (J.A.). (2009). Prevalencia y características de los síntomas externalizantes en la infancia. Diferencias de género. Psicothema, 21, 353-358.

Nunnally, J. C. (1978). Psychometric theory. (2. ${ }^{\mathrm{a}}$ edicion). New York: McGraw-Hill.

Olson, S. L., y Hoza, B. (1993). Preschool developmental antecedents of conduct problems in children beginning school. Journal of Clinical Child Psychology, 22, 60-67. doi: 10.1207/s15374424jccp2201_6.

Organización Mundial de la Salud, OMS. (1992). CIE-10. Trastornos mentales y del comportamiento. Madrid: Meditor.

Patterson, G. R., y Stoolmiller, M. (1991). Replications of a dual failure model for boys' depressed mood. Journal of Consulting and Clinical Psychology, 59, 491-498. doi: 10.1037/0022-006X.59.4.491.

Reddy, L. A., y Richardson, L. (2006). School-based prevention and intervention programs for children with emotional disturbance. Education and Treatment of Children, 29, 1-26.

Reinherz, H. Z., Giaconia, R. M., Carmola Hauf, A. M., Wasserman, M. S., y Paradis, A. D. (2000). General and specific childhood risk factors for depression and drug disorders by early adulthood. Journal of the American Academy of Child and Adolescent Psychiatry, 39, 223-231. doi: 10.1097/00004583-200002000-00023.

Reynolds, C. R., y Kamphaus, R. W. (1992). Behavior assessment system for children (BASC). Circle Pines, MN: American Guidance Services.

Roeser, R. W., Van der Wolf, K., y Strobel, K. R. (2001). On the relation between social-emotional and school functioning during early adolescence. Preliminary findings from Dutch and American samples. Journal of School Psychology, 39, 111-139. doi: 10.1016/S0022-4405(01)00060-7.

Romero, K., Canals, J., Hernández-Martínez, C., Jané, M.C., Viñas, F., y Domènech-Llaberia, E. (2010). Comorbilidad entre los factores de ansiedad del SCARED y la sintomatología depresiva en niños de 8-12 años. Psicothema, 22, 616-618.

Terry, D. (1994). Determinants of coping: The role of stable and situational factor. Journal of Personality and Social Psychology, 66, 895-910. doi: 10.1037/0022-3514.66.5.895.

Twenge, J. M., Gentile, B., DeWall, C. N., Ma, D., Lacefield, K., y Schurtz, D. R. (2010). Birth cohort increases in psychopathology among young Americans, 1938-2007: A cross-temporal meta-analysis of the MMPI. Clinical Psychology Review, 30, 145-154. doi: 10.1016/j.cpr.2009.10.005.

Yuan, K. H., y Bentler, P. M. (2000). Three likelihood-based methods for mean and covariance structure analysis with non normal missing data. En Sociological Methodology 2000 (pp. 165-200). Washington, DC: American Sociological Association. 
Joana Jaureguizar Albonigamayor, profesora agregada del Departamento de Psicología Evolutiva y de la Educación de la Escuela Universitaria de Magisterio (UPV/EHU) ha centrado su investigación en el estudio del comportamiento conflictivo de niños y adolescentes y sus relaciones familiares. El último proyecto de investigación en el que ha participado, ha analizado la depresión infantil en el contexto escolar de la Comunidad Autónoma Vasca.

Elena Bernaras Iturrioz, profesora titular del Departamento de Psicología Evolutiva y de la Educación de la Escuela Universitaria de Magisterio (UPV/EHU) ha centrado su investigación en el ámbito de la Educación Especial y más concretamente en el ámbito de la discapacidad visual y en el análisis de buenas prácticas de docencia en la universidad. Actualmente está trabajando en el análisis de la sintomatología depresiva en contextos escolares y su prevención.

Izaskun Ibabe Erostarbe, profesora titular del Departamento de Psicología Social y Metodología de las Ciencias del Comportamiento de la Facultad de Psicología (UPV/EHU), tiene una extensa experiencia docente sobre los métodos de investigación en las ciencias sociales. Cuenta con una amplia experiencia investigadora en el estudio de los factores de riesgo y protectores de los comportamientos violentos de los adolescentes en el ámbito familiar y escolar. En la actualidad su actividad investigadora está centrada en el estudio de la relación entre sintomatología depresiva y relaciones sociales en niños de la población general.

Marta Sarasa Maia, profesora del Departamento de Psicología Evolutiva y de la Educación de la Escuela Universitaria de Magisterio (UPV/EHU) tiene una amplia experiencia profesional en distintas Escuelas de la Comunidad Autónoma Vasca, centrando su labor dentro del marco de la Educación inclusiva y sobre todo en el ámbito de las necesidades educativas especiales y especialmente en la población con autismo y trastornos generalizados del desarrollo y sus familias. Actualmente, se encuentra realizando su tesis doctoral así como investigando a su vez la depresión infantil en el contexto escolar. 


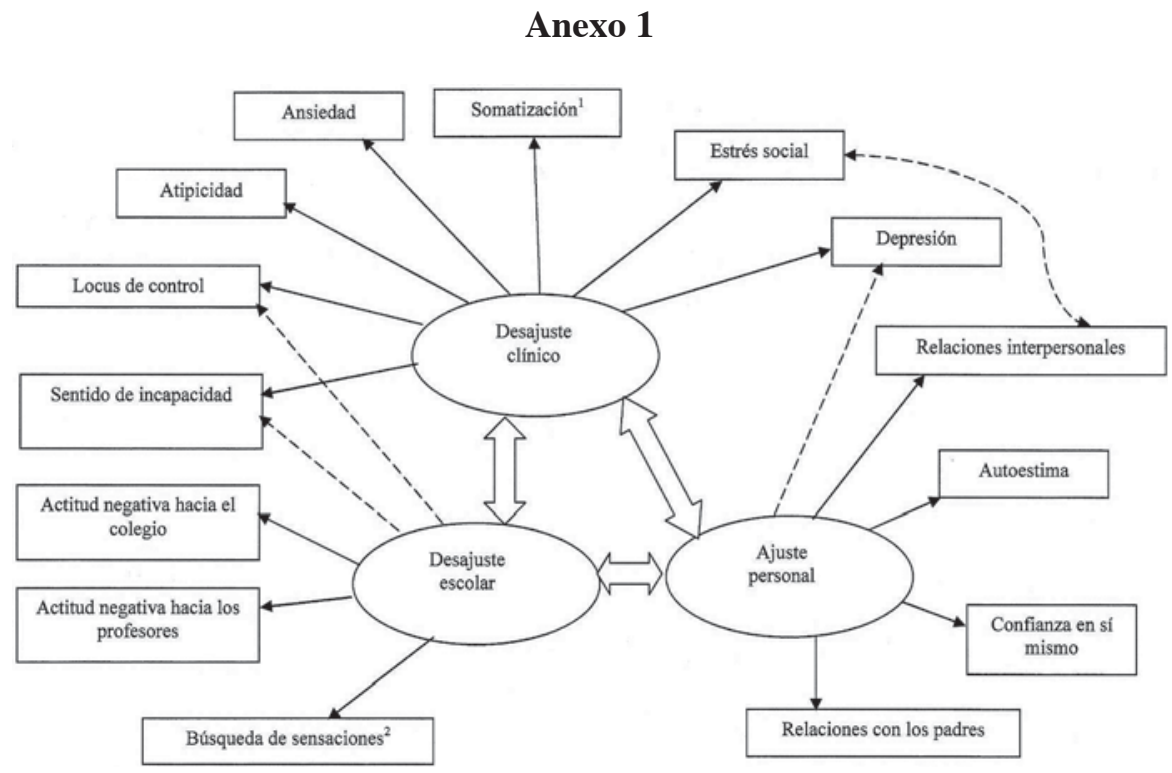

Nota: ${ }^{1} \mathrm{y}^{2}$ son variables correspondientes al instrumento BASC-S3 pero no se incluyen en el BASC-S2.

Figura 3. Modelo final del BASC en los estudios originales. 


\section{Anexo 2}

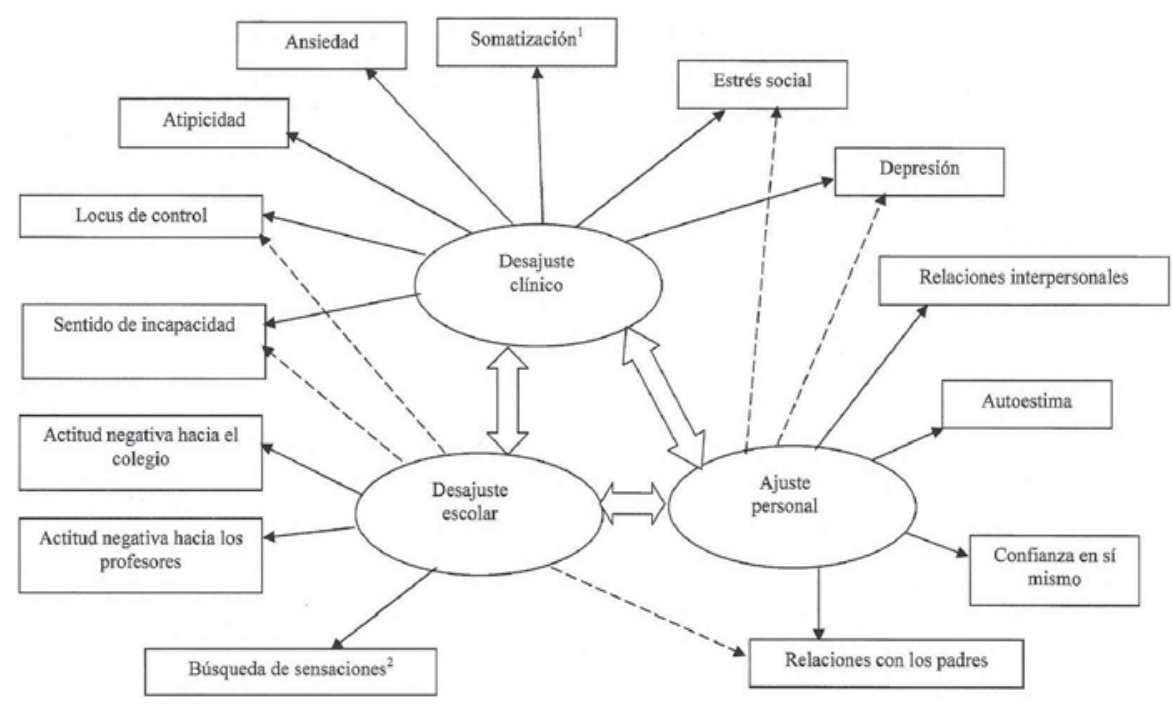

Nota: ${ }^{1} \mathrm{y}^{2}$ son variables correspondientes al instrumento BASC-S3 pero no se incluyen en el BASC-S2.

Figura 4. Modelo final del BASC en la adaptación española. 